\title{
Shortwave radiative forcing and efficiency of key aerosol types using AERONET data
}

\author{
O. E. García ${ }^{1, *}$, J. P. Díaz ${ }^{1}$, F. J. Expósito ${ }^{1}$, A. M. Díaz ${ }^{1}$, O. Dubovik ${ }^{2}$, Y. Derimian ${ }^{2}$, P. Dubuisson ${ }^{2}$, and J.-C. Roger ${ }^{3}$ \\ ${ }^{1}$ Grupo de Observación de la Tierra y la Atmósfera (GOTA), Universidad de La Laguna, Tenerife, Spain \\ ${ }^{2}$ Laboratoire d'Optique Amosphérique, Université des Sciences et Technologies de Lille, Villeneuve d'Ascq, France \\ ${ }^{3}$ Laboratoire de Météorologie Physique, Université Blaise Pascal, Clermont-Ferrand, France \\ *now at: Centro de Investigación Atmósferica de Izaña (CIAI), Agencia Estatal de Meteorología (AEMET), Spain
}

Correspondence to: O. E. García (ogarciar@aemet.es)

Received: 30 November 2011 - Published in Atmos. Chem. Phys. Discuss.: 12 December 2011

Revised: 16 May 2012 - Accepted: 24 May 2012 - Published: 12 June 2012

\begin{abstract}
The shortwave radiative forcing $(\Delta F)$ and the radiative forcing efficiency $\left(\Delta F^{\mathrm{eff}}\right)$ of natural and anthropogenic aerosols have been analyzed using estimates of radiation both at the Top (TOA) and at the Bottom Of Atmosphere (BOA) modeled based on AERONET aerosol retrievals. Six main types of atmospheric aerosols have been compared (desert mineral dust, biomass burning, urbanindustrial, continental background, oceanic and free troposphere) in similar observational conditions (i.e., for solar zenith angles between $55^{\circ}$ and $65^{\circ}$ ) in order to compare the nearly same solar geometry. The instantaneous $\Delta F$ averages obtained vary from $-122 \pm 37 \mathrm{Wm}^{-2}$ (aerosol optical depth, AOD, at $0.55 \mu \mathrm{m}, 0.85 \pm 0.45$ ) at the BOA for the mixture of desert mineral dust and biomass burning aerosols in West Africa and $-42 \pm 22 \mathrm{Wm}^{-2}(\mathrm{AOD}=0.9 \pm 0.5)$ at the TOA for the pure mineral dust also in this region up to $-6 \pm 3 \mathrm{Wm}^{-2}$ and $-4 \pm 2 \mathrm{Wm}^{-2}(\mathrm{AOD}=0.03 \pm 0.02)$ at the $\mathrm{BOA}$ and the TOA, respectively, for free troposphere conditions. This last result may be taken as reference on a global scale. Furthermore, we observe that the more absorbing aerosols are overall more efficient at the $\mathrm{BOA}$ in contrast to at the TOA, where they backscatter less solar energy into the space. The analysis of the radiative balance at the TOA shows that, together with the amount of aerosols and their absorptive capacity, it is essential to consider the surface albedo of the region on which they are. Thus, we document that in regions with high surface reflectivity (deserts and snow conditions) atmospheric aerosols lead to a warming of the Earthatmosphere system.
\end{abstract}

\section{Introduction}

Solar radiation is the main source of energy for the Earthatmosphere system, and directly or indirectly, is responsible for all phenomena affecting the meteorology and climatology of this system. The variation of any component of this system affects the radiative equilibrium, resulting in, for example, changes in the temperature of the system and/or in the configuration of the atmospheric circulation. In order to quantify these effects the concept of radiative forcing was introduced in the literature that shows magnitude of changes in the radiative balance due to changes in a specific atmospheric component, for instance, clouds, atmospheric gases or atmospheric aerosols.

One of the main reasons for the changes in the energy balance of the Earth-atmosphere system is the variation in the concentration of the greenhouse gases, GHGs, which contribute to an increase in the system temperature. On a global scale, the total annual anthropogenic emissions of GHGs have increased $70 \%$ between 1970 and 2004 with respect to the pre-industrial era (IPCC, 2007). The associated radiative forcing of this increase is expected to be $+2.3 \mathrm{Wm}^{-2}$, with an uncertainty of $\pm 0.2 \mathrm{Wm}^{-2}$ (IPCC, 2007).

On the other hand, another decisive factor is atmospheric aerosol, both from a natural and anthropogenic origin. These atmospheric constituents, directly and indirectly, modify the energy balance of the Earth-atmosphere system: directly through the absorption and dispersion of solar radiation in the atmosphere and, indirectly, by acting as nuclei of cloud condensation and modifying the cloud properties (albedo, 
reflectivity, lifetime, precipitation efficiency,...) (Twomey, 1977; Charlson et al., 1987; Lohmann and Feichter, 2005). Finally, there are semi-direct effects associated with the absorption of solar radiation by aerosols. These produce an unequal warming of the atmosphere, contributing to the modification of cloud characteristics (Ackerman et al., 2000; Koren et al., 2004).

The atmospheric aerosols mainly cool the climatic system and, therefore, counteract greenhouse gas warming (IPCC, 2007). For example, anthropogenic aerosols (mostly sulphates, organic carbon, soot, nitrates and mineral particles) jointly produce a cooling effect with a direct radiative forcing of $-0.5(-0.9$ and -0.1$) \mathrm{Wm}^{-2}$ at the global level, while they cause an indirect radiative forcing, associated with the modification of the cloud albedo, of $-0.7(-1.8$ and $-0.3) \mathrm{Wm}^{-2}$ (IPCC, 2007). Regarding natural aerosols, the desert mineral dust is the main aerosol emitted on a global scale (Satheesh and Moorthy, 2005) and, therefore, plays a decisive role in the energy balance of the climatic system. Recent studies show, for instance, that the direct radiative forcing of these aerosols varies between -0.6 and $+0.1 \mathrm{Wm}^{-2}$ on a global scale (IPCC, 2007), although the local effects can be far greater and reach hundreds of $\mathrm{Wm}^{-2}$, mainly in those regions close to the emission sources (García et al., 2011a; Haywood et al., 2003).

These values clearly indicate significant uncertainties in the aerosol radiative forcing estimates and confirm the need to study their radiative properties and to adequately quantify their effects on radiative balance. In fact, according to the recent report of IPCC (2007), the direct radiative forcing of the individual aerosol species is less certain than the total direct radiative forcing by all aerosols. Likewise, recent studies show that most climate models underestimate the negative forcing by anthropogenic aerosols (Hansen et al., 2011). In this context, the long-term monitoring of different aerosol types is crucial to improve our knowledge of the radiative forcing and climate parameters. Nowadays, one of the most useful tools supporting this aim is the AErosol RObotic NETwork (AERONET, http://aeronet.gsfc.nasa.gov), which provides enough information globally to establish a groundbased aerosol climatology and to analyze the most influential aerosols on the climatic system. An extended set of physical and optical aerosol properties, averaged in the atmospheric column Dubovik et al. (2002b, 2006) and given at more than two hundred globally distributed stations, have enabled verification of global aerosol models and satellite retrievals.

In this context, given the importance of atmospheric aerosols on the energy balance of the Earth-atmosphere system and the uncertainties that still present, the main objective of this study is to analyze the direct radiative forcing and the radiative forcing efficiency of key aerosol types with a homogeneous methodology. The latter, based on the AERONET retrievals, is described in detail in Sect. 2 of this paper. Section 3 presents the regions analyzed and the aerosols predominant over them: desert mineral dust, biomass burning, urban-industrial, continental background, oceanic and free troposphere. The analysis of the direct radiative forcing and radiative forcing efficiency at the top and at the bottom of the atmosphere is shown and discussed in Sect. 4 and, finally, the main remarks are summarized in Sect. 5.

\section{Methodology and data}

Direct radiative forcing from atmospheric aerosols, denoted as $\Delta F$, is defined as the difference in the energy levels between a situation where aerosols are present, $F^{\mathrm{A}}$, and a situation where these atmospheric particles are absent, $F^{\mathrm{C}}$ (Eq. 1):

$\Delta F=\left(F^{\downarrow \mathrm{A}}-F^{\uparrow \mathrm{A}}\right)-\left(F^{\downarrow \mathrm{C}}-F^{\uparrow \mathrm{C}}\right)$

where the arrows indicate the direction of the global fluxes: $\downarrow=$ downward flux and $\uparrow=$ upward flux. This study analyzes these values at the Top Of Atmosphere (TOA) in addition to the Bottom Of Atmosphere (BOA). Thus, radiative forcing can be defined at these two levels as:

$$
\Delta F \mathrm{TOA}=F_{\mathrm{TOA}}^{\uparrow \mathrm{C}}-F_{\mathrm{TOA}}^{\uparrow \mathrm{A}}
$$

$\Delta F \mathrm{BOA}=\left(F_{\mathrm{BOA}}^{\downarrow \mathrm{A}}-F_{\mathrm{BOA}}^{\downarrow \mathrm{C}}\right) \cdot(1-S A)$

where SA is the surface albedo. This sign criterion implies that negative values of $\Delta F$ are associated with an aerosol cooling and positive values with aerosol warming effects either at the BOA or at the TOA.

The aerosol radiative forcing provides the actual or total radiative effect of atmospheric aerosols, but in order to make a consistent comparison among them the aerosol radiative forcing efficiency, $\Delta F^{\text {eff }}$, is a magnitude more appropriate. This magnitude is defined as the rate at which the atmosphere is forced per unit of aerosol optical depth, AOD, at $0.55 \mu \mathrm{m}$ and, thus, the influence of the aerosol load is ruled out of radiative forcing:

$\Delta F^{\mathrm{eff}}$ level $=\frac{\Delta \mathrm{F}_{\text {level }}}{\mathrm{AOD}}$

where "level" means at the BOA or at the TOA.

In this work we use the $\Delta F$ values operationally provided at any location in the AERONET webpage as an operational product of AERONET network (http://aeronet. gsfc.nasa.gov). The AERONET $\Delta F$ is defined according to Eqs. (5) and (6), whereby only considers the downward fluxes at the BOA and the upward fluxes at the TOA :

$\Delta F \mathrm{BOA}_{\mathrm{AER}}=\left(\mathrm{F}_{\mathrm{BOA}}^{\downarrow \mathrm{A}}-\mathrm{F}_{\mathrm{BOA}}^{\downarrow \mathrm{C}}\right)$

$\Delta F \mathrm{TOA}_{\mathrm{AER}}=\left(\mathrm{F}_{\mathrm{TOA}}^{\uparrow \mathrm{C}}-\mathrm{F}_{\mathrm{TOA}}^{\uparrow \mathrm{A}}\right)$ 
The definition of $\Delta F$ at the TOA coincides with the general definition (Eq. 2), but the AERONET's $\Delta F$ at the BOA overestimates the real values, since the upward fluxes with and without aerosols are not taken into account. In order to correct the latter, the AERONET's $\Delta F$ values at the BOA have been corrected by the term (1-SA) to consider the upward fluxes at the BOA. To do so, we consider a unique value of the spectral SA for each almucantar retrieval, which is obtained from the spectral average of the surface albedo calculated by V2 AERONET algorithm at $0.44,0.67,0.87$ and $1.02 \mu \mathrm{m}$. These SA spectral values are also given at any location in the AERONET webpage as an operational product of AERONET network.

The broadband fluxes in the solar spectrum $(0.2-4.0 \mu \mathrm{m})$ with the presence or absence of aerosols $\left(F^{\mathrm{A}}\right.$ and $\left.F^{\mathrm{C}}\right)$ were calculated as a part of the AERONET network (AERosol RObotic NETwork, Holben et al., 1998) processing, where $F^{\mathrm{A}}$ and $F^{\mathrm{C}}$ are estimated based on aerosol parameters inverted from radiometer observation as described by Dubovik and King (2000); Dubovik et al. (2006). Specifically, the broadband fluxes were calculated by a correspondent module of radiative transfer model GAME (Global Atmospheric ModEl) (Dubuisson et al., 1996, 2006; Roger et al., 2006) that has been integrated into operational AERONET inversion code and provides the fluxes and aerosol radiative forcing values as part of AERONET operational product. This module accurately accounts for the molecular scattering and gaseous absorption effects. Specifically, the gaseous absorption (mainly $\mathrm{H}_{2} \mathrm{O}, \mathrm{CO}_{2}$, and $\mathrm{O}_{3}$ ) is calculated from the correlated $k$-distribution (Lacis and Oinas, 1991). The use of correlated $k$-distribution allows accounting for interactions between gaseous absorption and multiple scattering with acceptably short computational time for providing broadband fluxes within AERONET operational procedure. The coefficients of the correlated $k$-distribution have been estimated from reference calculations using a line-by-line code (Dubuisson et al., 2004). Assessment of water vapor content is based on the instantaneous water vapor values retrieved by AERONET using absorption differential method at the $0.94 \mu \mathrm{m}$ channel (Smirnov et al., 2004). The ozone content was fixed using the monthly climatology values of the total ozone content obtained from NASA Total Ozone Mapping Spectrometer (TOMS) measurements from 1978 to 2004. Other atmospheric gaseous profiles were obtained from US standard 1976 atmosphere model.

The spectral integration was done in the range from 0.2 to $4.0 \mu \mathrm{m}$ using more than 200 spectral sub-intervals. For each of these sub-intervals the extinction, single scattering albedo and phase function were recalculated using exact AERONET aerosol model driven by retrieved size distribution, complex refractive index and fraction of spherical particles (the details of this model were developed in studies by Dubovik and King, 2000; Dubovik et al., 2006 and clearly summarized in paper by Dubovik et al., 2011). The values of the complex refractive index for each of 200 spectral sub-intervals were interpolated or extrapolated from the values retrieved at AERONET operational wavelengths. The effects of multiple scattering in broadband integration were accounted by discrete ordinates radiative transfer code using 12 moments of Legendre polynomials expansion of aerosol phase matrices. The surface spectral reflectance was modeled using climatological values provided by MODIS space instrument, that were spectrally interpolated or extrapolated in similar manner as it was done for complex refractive index.

The appropriate characterization of the surface albedo is a critical issue to estimate aerosol radiative effect (Myhre et al., 2003) as well as an important error source in the retrieval of aerosol properties (Dubovik et al., 2000; Sinyuk et al., 2007). For that reason, the surface reflectance is approximated by a bidirectional reflectance distribution function (BRDF): CoxMunk model for over water (Cox and Munk, 1954) and by Ross-Li model over land (Ross, 1981; Li and Strahler, 1992; Wanner et al., 1995). The BRDF parameters for land sites are adopted from MODIS Ecotype generic BRDF models (courtesy of Feng Gao, NASA/GSFC). The BRDF models are mixed according to Ecotype map of Moody et al., 2005, 2008 and NISE SSM/I snow and ice extent and MODIS snow cover map. For Cox-Munk calculations we adopted the wind speed from NCEP/NCAR Reanalysis data.

The AERONET estimates of solar fluxes, radiative forcing and forcing efficiency are calculated for the whole range of AOD values, being the uncertainty in retrieved single scattering albedo $(\omega)$ quite high, typically $>0.05$ at the low AOD levels (Dubovik et al., 2000). Nevertheless, the increase of errors for $\omega$ with decrease of AOD is not critical for estimations of fluxes. This is due to the diffuse fluxes and the influence of aerosol on radiation fluxes decrease when AOD diminishes. In addition, while the accuracy of $\omega$ decreases with decrease of aerosol loading, the error in absorption optical thickness stays constant at the level of 0.01 and, therefore, the error in flux stays also rather constant. In fact, the comparison results for broadband solar fluxes and radiative forcing at surface shows that these uncertainties for low AOD do not seem decisive in the solar fluxes simulations due to modest impact of atmospheric aerosols. Moreover, we did not observed significant differences between modeled and measured fluxes for small AOD. The mean differences between observed and modeled magnitudes only show a smooth increase for high AOD (please refer to Fig. 4b of García et al., 2008).

In that work, García et al. (2008), using ground-based solar measurements under different aerosol environments, found that the straight forward comparison between the observed and modeled solar irradiance shows an excellent agreement (slope of $0.98 \pm 0.00$ and bias of $-5.32 \pm 1.00$ ), with a correlation of $99 \%$. As a result, in global terms, a small overestimation of $9 \pm 12 \mathrm{Wm}^{-2}$ was found on observed solar radiation, which means a relative error of $2.1 \pm 3.0 \%$. For each aerosol type, these differences range from $-2 \pm 8$ to $-3 \pm 7 \mathrm{Wm}^{-2}$ under continental background, from $8 \pm 9$ to $16 \pm 10 \mathrm{Wm}^{-2}$ for stations with 
mineral dust conditions, $14 \pm 10 \mathrm{Wm}^{-2}$ and $6 \pm 13 \mathrm{Wm}^{-2}$ for urban-industrial and biomass burning aerosols respectively, lower than $13 \pm 10 \mathrm{Wm}^{-2}$ in oceanic environments and $2 \pm 10 \mathrm{Wm}^{-2}$ in the free troposphere conditions observed at the Mauna Loa Observatory. These errors are expected to be of the same magnitude at the TOA, since the same methodology is used in both cases (gaseous and aerosol distribution, radiative model, etc.). Also, the comparisons of AERONET calculated broadband fluxes with surface flux measurements collected during AMMA campaign showed the agreement simulated fluxes with measurements within $10 \%$ or better (Derimian et al., 2008).

The AERONET network retrieves measures of microphysical and optical properties of aerosols, such as particle size distribution, refraction index, detailed scattering and absorption properties from more than two hundred globally distributed stations. For that, the level of accuracy in the CIMEL measurements is a critical issue in the inversion process, since the retrieval algorithm is set to fit the data to the level of AERONET measurement uncertainty, i.e., the nominal error in AOD is assumed $0.015 \cdot \cos$ (sza) (sza $=$ solar zenith angle), while for sky radiance measurements the error is $\pm 5 \%$. These values are determined by calibration conditions. For the direct measurements, the calibration of field instruments is performed by a transfer of the calibration from reference CIMELs, which are calibrated by the Langley plot technique at Mauna Loa Observatory (Hawaii). Typically, the total uncertainty in spectral aerosol optical depth for the field instruments ranges from 0.01 to 0.02 under cloud-free conditions for air mass equal one Eck et al. (1999), with the highest errors $(0.02)$ associated with the ultraviolet wavelengths. For the sky radiance measurements, the calibration is performed by comparing to a reference integrating sphere with an accuracy of $\pm 5 \%$ or better at the NASA Goddard Calibration Facility (Holben et al., 1998). As discussed in papers by Dubovik et al. (2000, 2002a), the AERONET retrieved aerosol properties have the highest accuracy for observation when sza is between $50^{\circ}$ and $80^{\circ}$. Since the radiative forcing strongly depends on sza (Derimian et al., 2008), the radiative analysis presented here have been limited at sza of $60 \pm 5^{\circ}$ in order to compare the nearly same solar geometry (Sects. 4.2 and 4.3). This interval concentrates the maximum number of AERONET's almucantar retrievals and, thus, it can be representative of the AERONET's inversion data set $\left(50^{\circ}-80^{\circ}\right)$. The measures used here were taken from the second version of the inversion processing based on spheroid applying aerosol model by Dubovik et al. (2006) and using surface reflectance values provided by MODIS climatology. The cloud-clear level 2 cases (L2) were selected by Smirnov et al. (2000) algorithm and assured later manual reviewing as required by AERONET's Version 2 Quality Assurance Criteria (hereinafter $\mathrm{V} 2-\mathrm{AQC}$ ).

Note that $\triangle F \mathrm{BOA}_{\mathrm{AER}}$ has been calculated only considering the $\mathrm{SA}$ averaged at the AERONET inversion channels instead of the spectral SA values in the whole solar range
Table 1. AERONET stations grouped into aerosol type and region ( $N 1$ is the number of almucantar retrievals at the sza range $50^{\circ}$ $80^{\circ}$ and $N 2$ is the number of almucantar retrievals at the sza range $55^{\circ}-65^{\circ}$ for each station).

\begin{tabular}{|c|c|c|c|c|c|}
\hline Aerosol & Region & Station & Period & $N 1$ & $N 2$ \\
\hline \multirow[t]{3}{*}{ MD } & North & S/C Tenerife & $2005-2007$ & 416 & 151 \\
\hline & Africa R1 & Dahkla & $2002-2003$ & 758 & 211 \\
\hline & & Saada & 2004-2006 & 1730 & 534 \\
\hline \multirow[t]{4}{*}{ MD } & West & DMN Maine & 2007-2008 & 1529 & 280 \\
\hline & Africa R2 & Banizoumbou & 1995-2007 & 4796 & 1476 \\
\hline & & Ilorin & 1998-2006 & 942 & 255 \\
\hline & & Djougou & 2004-2007 & 1741 & 513 \\
\hline \multirow[t]{3}{*}{ MD } & Arabian & Sede Boker & 1996-2005 & 5714 & 1953 \\
\hline & Peninsula R3 & Solar Village & 1999-2006 & 8369 & 2577 \\
\hline & & Bahrain & 1999-2002 & 1060 & 458 \\
\hline \multirow[t]{3}{*}{ MD } & Asia R4 & Sacol & 2006-2007 & 900 & 306 \\
\hline & & Dalanzadgad & 1997-2007 & 1504 & 436 \\
\hline & & Yulin & 2001-2002 & 511 & 135 \\
\hline \multirow[t]{5}{*}{ BB } & Southern & Alta Floresta & 1993-2006 & 996 & 328 \\
\hline & America R5 & Abracos Hill & 1999-2005 & 808 & 264 \\
\hline & & Balbina & 1999-2002 & 212 & 75 \\
\hline & & Belterra & 1999-2004 & 420 & 107 \\
\hline & & Rio Branco & $2000-2005$ & 404 & 140 \\
\hline \multirow[t]{4}{*}{ BB } & Southern & Zambezi & 1996-1997 & 263 & 67 \\
\hline & Africa R6 & & 2000 & & \\
\hline & & Skukuza & 1998-2007 & 3206 & 1441 \\
\hline & & Mongu & 1995-2005 & 4382 & 1424 \\
\hline \multirow[t]{2}{*}{ BB } & North & Waskesiu & 1994-2006 & 940 & 323 \\
\hline & America R7 & Thompson & 1994-2002 & 229 & 95 \\
\hline \multirow[t]{2}{*}{ UI } & Europe & Lille & 1999-2006 & 990 & 275 \\
\hline & $\mathrm{R} 8$ & Ispra & 1997-2007 & 2192 & 672 \\
\hline \multirow[t]{3}{*}{ UI } & North & GSFC & $1993-2006$ & 5720 & 1833 \\
\hline & America R9 & Baltimore & 1999-2007 & 4058 & 1316 \\
\hline & & CCNY & 2002-2008 & 609 & 270 \\
\hline \multirow[t]{6}{*}{ UI } & Asia R10 & Anmyon & 1999-2002 & 1362 & 451 \\
\hline & & & 2004-2006 & & \\
\hline & & Shirahama & 2000-2006 & 1829 & 563 \\
\hline & & Gosan & 2001-2006 & 474 & 163 \\
\hline & & NCU Taiwan & 1998-2006 & 280 & 113 \\
\hline & & Beijing & 2001-2008 & 2688 & 949 \\
\hline \multirow[t]{2}{*}{ CB } & Europe R11 & Yekaterinburg & $2004 / 2006$ & 165 & 50 \\
\hline & & Toravere & 2002-2004 & 277 & 99 \\
\hline \multirow[t]{3}{*}{ CB } & North & Bratts Lake & 1999-2007 & 1362 & 317 \\
\hline & America R12 & Saturn Island & 1999-2006 & 603 & 291 \\
\hline & & Sevilleta & 1994-2006 & 5907 & 1787 \\
\hline \multirow[t]{4}{*}{$\mathrm{O}$} & Atlantic & Bermuda & 1996 & 334 & 122 \\
\hline & Ocean R13 & & 1998-2002 & & \\
\hline & Pacific & Lanai & 1996-2004 & 1554 & 428 \\
\hline & Ocean R13 & Nauru & 1999-2003 & 82 & 23 \\
\hline \multirow[t]{2}{*}{ FT } & Atlantic & Izaña & 2004-2006 & 616 & 188 \\
\hline & Pacific & Mauna Loa & 1999-2006 & 494 & 85 \\
\hline
\end{tabular}




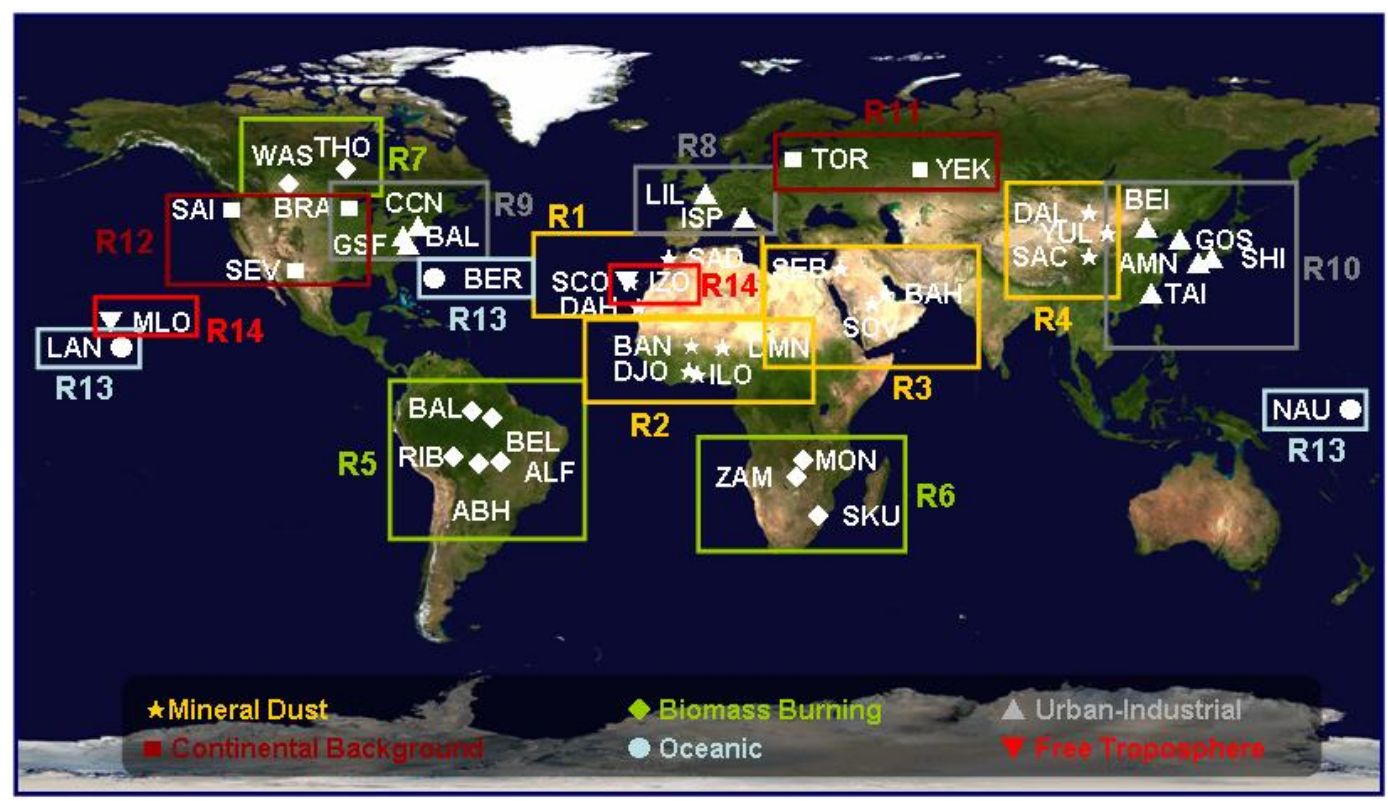

Fig. 1. Geographical distribution of the AERONET stations used. These stations were grouped into 14 regions, according to key aerosol types and their geographic location. Each aerosol type is labeled with a different symbol: mineral dust as stars, biomass burning as diamonds, urban-industrial as triangles, background continental as squares, oceanic as dots and free troposphere as inverted triangles.

$(0.2-4.0 \mu \mathrm{m})$, since the latter is not provided as an operational AERONET product. Therefore, in order to estimate the possible uncertainties introduced by the SA assumed we have compared the radiative forcing at the BOA calculated by: (1) using the operational AERONET SA averaged at the AERONET inversion channels (i.e, only four wavelengths at $0.44,0.67,0.87$ and $1.02 \mu \mathrm{m}, \Delta F \mathrm{BOA}_{\mathrm{AER}}$ ), and (2) considering the spectral solar upward fluxes and the spectral surface albedo in the whole solar spectral range $(0.2-4.0 \mu \mathrm{m})$ in the same manner as it is used in the AERONET retrieval algorithm. To do so, we have considered the AERONET stations used in the study of García et al. (2008), which have different range of surface albedo (vegetation, desert, snow, ocean). Our tests document a mean difference less than $10 \%$. Therefore, considering the surface albedo averaged at the four AERONET wavelengths $(0.44,0.67,0.87$ and $1.02 \mu \mathrm{m})$ may be a good approximation for evaluating the aerosol radiative forcing at surface.

\section{Description of the regions}

In order to analyze the radiative effect of key aerosols types we selected a set of forty three AERONET stations, which have been grouped into 14 regions taking the predominant aerosol and the proximity to source areas into account. The aerosol types considered have shown the greatest influence on the radiative balance, according to their rates of emission to the atmosphere and radiative properties (Dubovik et al., 2002a; Satheesh and Moorthy, 2005; IPCC, 2007): desert mineral dust introduced into the atmosphere by erosive processes; biomass burning produced by tropical farming activities and forest fires; urban-industrial and continental background particles; oceanic aerosols and those that are found in free troposphere conditions. The geographical distribution of these stations is displayed on the Fig. 1, while the Table 1 summarizes the regions and stations used and presents data information like the period or the data set for each station. The key aerosol types in Table 1 are labeled as: $\mathrm{MD}=$ Mineral Dust, $\mathrm{BB}=$ Biomass Burning, $\mathrm{UI}=$ Urban Industrial, $\mathrm{CB}=$ Continental Background, $\mathrm{O}=$ Oceanic and FT $=$ Free Troposphere.

It should be noted that the stations selected in this work have been widely used in earlier studies about the influence of aerosols on radiative transfer and climate (Díaz et al., 2001; Eck et al., 2001; Holben et al., 2001; Schafer et al., 2002; Dubovik et al., 2002a; García et al., 2008, 2011a,b).

\subsection{Desert dust}

The mineral dust was categorized into four groups to study their radiative properties. Each group takes into consideration the different source areas and the possible mixtures with other aerosol types. It is important to mention that all of these mineral dust regions are located within "dust belt" (5$40^{\circ} \mathrm{N}$ ), where the mineral dust concentrations are maximal on a global scale (Prospero et al., 2002).

The region 1 (R1) is made up of those stations located in northern Africa (Saada - SAD, Santa Cruz de Tenerife - SCO, and Dahkla - DAH), whose main contributions of 

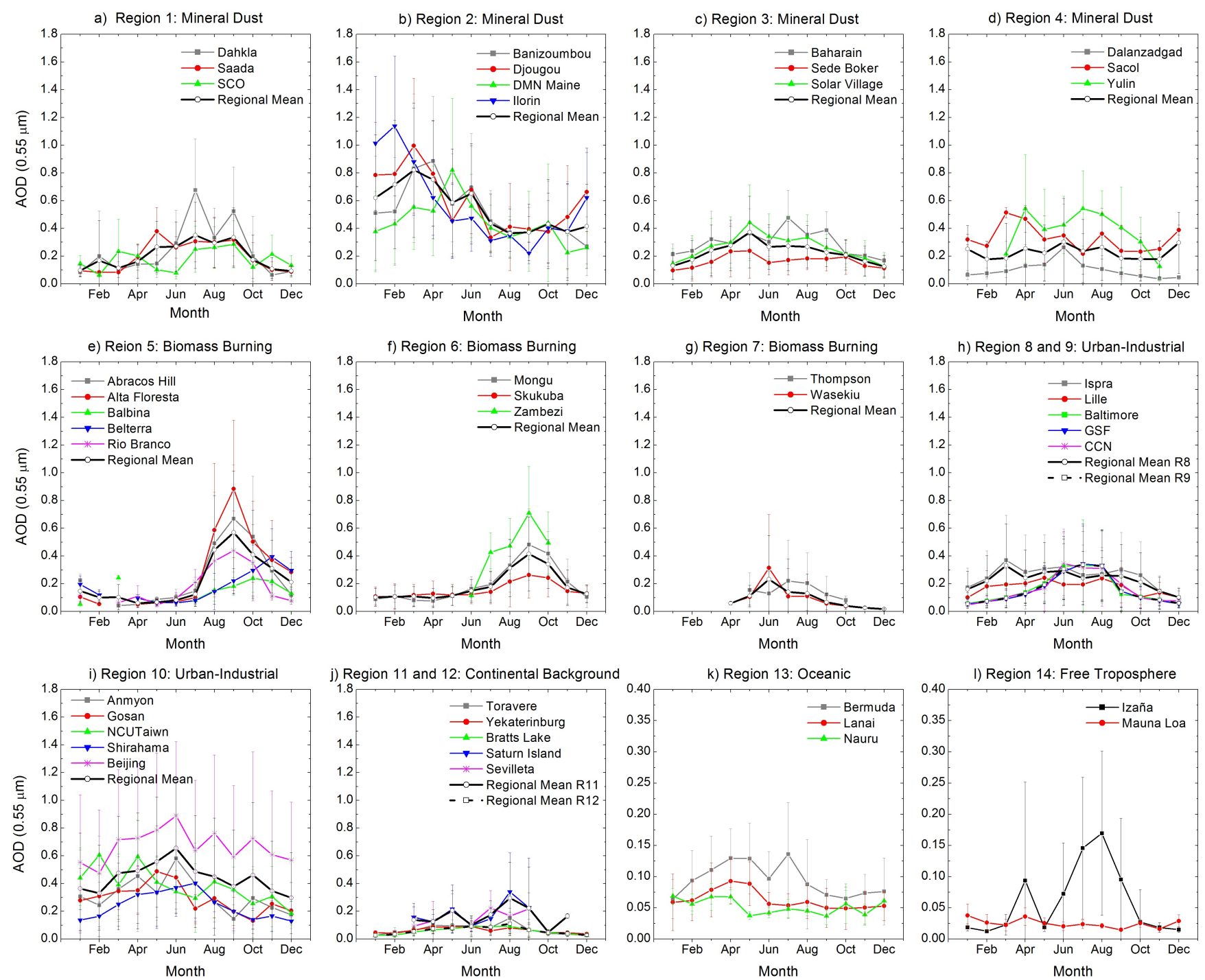

Fig. 2. Monthly evolution of the multi-year average of the aerosol optical depth, AOD, at $0.55 \mu \mathrm{m}$ for each station of region 1 (a), region 2 (b), region 3 (c), region 4 (d), region 5 (e), region 6 (f), region 7 (g), region 8 and 9 (h), region 10 (i), region 11 and 12 (j), region 13 (k) and region 14 (l). The annual cycle of the regional mean is also shown (black lines). Error bars indicate $\pm 1 \sigma$ ( $\sigma$, standard deviation).

crustal material come from Morocco, Mauritania, the western Sahara, Tunisia, northern and eastern Algeria (Prospero et al., 2002). To a lesser extends, these stations can also be affected by anthropogenic aerosols from the European or African continent besides local pollution (Díaz et al., 2006; Rodríguez et al., 2011). Thus, the seasonality of the aerosol content in this region is dominated by mineral dust emissions from North Africa, achieving the maximal activity in summer (June-August). During this period large quantities of mineral dust are transported across the Mediterranean to Europe, Middle East and to the American continent (Caribbean and eastern coast of the US) crossing the Atlantic Ocean (Prospero et al., 2002). This seasonality is shown in Fig. 2, which depicts the monthly evolution of the multi-year average of the aerosol optical depth (AOD) at $0.55 \mu \mathrm{m}$ for all stations grouped into regions and the regional averages. The AOD annual cycles were calculated with the AOD L2 almucantar retrievals (sza between $50^{\circ}-80^{\circ}$ ). Thus, for the region 1 the AOD values are between $\sim 0.2-0.6$ from June to September (Fig. 2a), while the AOD multi-year average is $0.2 \pm 0.2$ (hereafter, the errors are given as \pm one standard deviation). North African mineral dust emissions are also frequent during the winter (December-February), reducing the activity during the spring (March-May) and the autumn (SeptemberNovember) (Prospero et al., 2002; Díaz et al., 2006). Nevertheless, the latter behavior is not clearly observed in the period studied in this work (Table 1 and Fig. 2a).

Region 2, R2 (Maine Soroa - DMN, Banizoumbou BAN, Ilorin - ILO, and Djougou - DJO), is immersed in the savannah of West Africa and located quite near to the Sahara- 

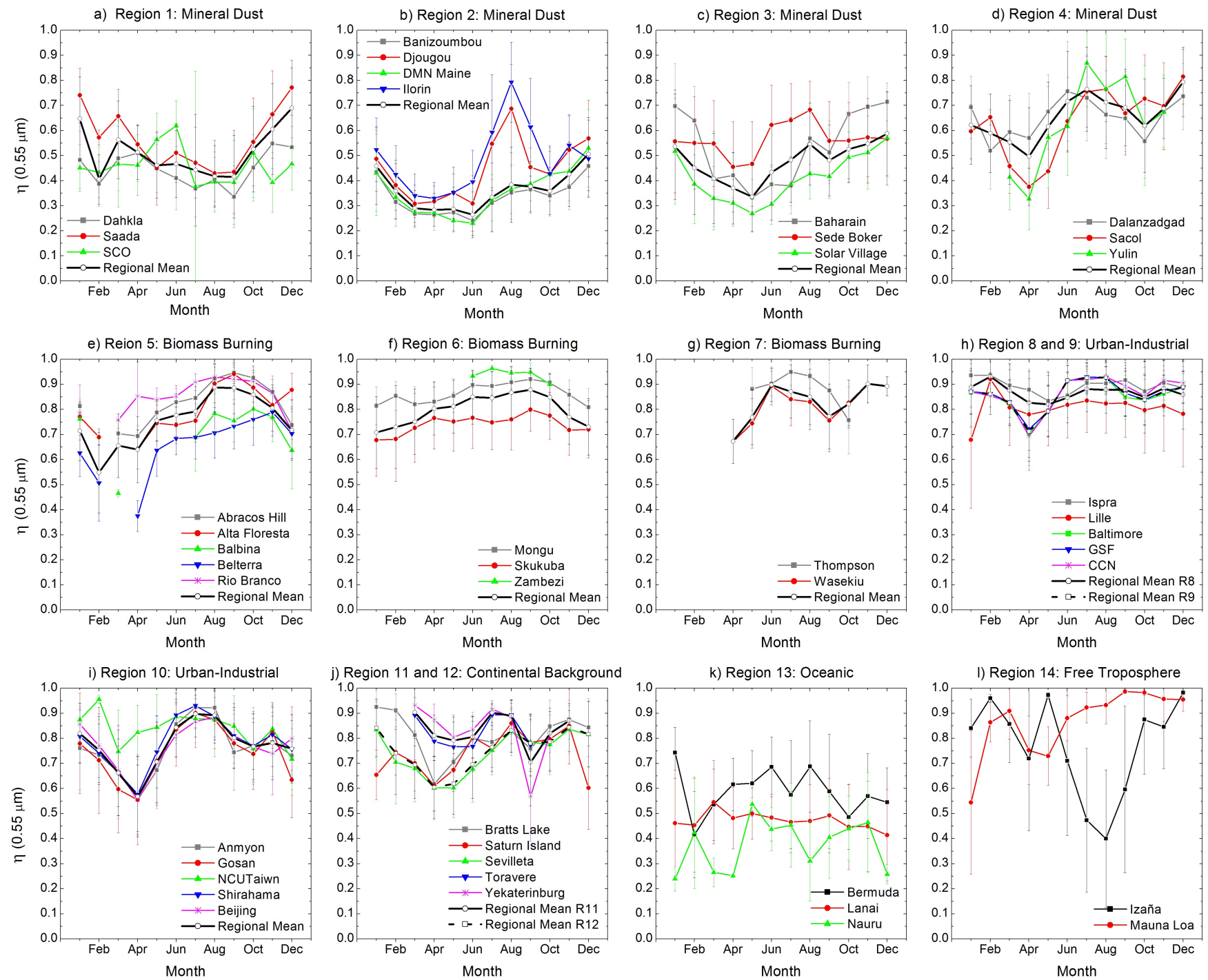

Fig. 3. Monthly evolution of the multi-year regional average of the fine aerosol fraction, $\eta$, at $0.55 \mu \mathrm{m}$ for each station of region 1 (a), region $2(\mathbf{b})$, region $3(\mathbf{c})$, region $4(\mathbf{d})$, region $5(\mathbf{e})$, region $6(\mathbf{f})$, region $7(\mathbf{g})$, region 8 and $9(\mathbf{h})$, region $10(\mathbf{i})$, region 11 and $12(\mathbf{j})$, region $13(\mathbf{k})$ and region 14 (l). The annual cycle of the regional mean is also shown (black lines). Error bars indicate $\pm 1 \sigma$ ( $\sigma$, standard deviation).

Sahel desert area and, therefore, affected by the desert areas found in Niger, southern Algeria and Libia, Lake Chad Basin and Bodele Depression (Prospero et al., 2002; Holben et al., 2001). It is under high emission rates of biomass burning and mineral dust, the latter almost constantly throughout the year. The combination of these two types of aerosols usually takes place during the winter (Fig. 2b), which is the season with the greatest activity of biomass burning in Central Africa. In order to distinguish the predominant aerosol and the mixture situations, the monthly evolution of the multi-year average of the fine aerosol fraction $(\eta)$ at $0.55 \mu \mathrm{m}$ have been also analyzed for all regions (Fig. 3). This parameter is defined as the fraction of the total optical depth attributed to the fine mode of the aerosol size distribution. The combination of AOD and $\eta$ information allows us to discriminate aerosols with simi- lar solar extinction but different sizes, such as mineral dust and biomass burning particles. Thus, due to the contribution of biomass burning aerosols in winter, the high AOD values (regional mean value of $0.6 \pm 0.4$ ) are associated with an increase in the fine mode of the size distribution, leading an increase of $\eta$ (regional mean value of $0.4 \pm 0.2$ ) (Fig. 3a). The observed values of $\eta(\sim 0.2-0.6)$, although higher than rest of the year, do not correspond to those measured for pure biomass burning, which are between 0.7-1.0 (Kaufman et al., 2005), and indicate combined contributions of mineral dust and biomass burning particles. Lower single scattering albedo and effective radius were also observed (please see García et al. (2011a) for analysis in detail). Consequently, the aerosol mixture in winter has greater absorption capacity than the pure mineral, since the biomass burning particles 
(mainly elemental carbon) enhance the absorption of solar radiation. This situation is reversed during spring. From March to May, the aerosol emissions are only influenced by desert material, which leads to the maximal regional annual values of AOD and minimal ones of $\eta$ (Fig. 3b): $0.7 \pm 0.5$ and $0.3 \pm 0.1$, respectively.

Region 3, R3, includes the Middle East (Sede Boker SEB, Solar Village - SOV and Bahrain - BAH), where the crustal material from the Arabian Peninsula's deserts is the predominant aerosol during the entire year, with the highest intensity during spring and summer (Fig. 2c). Prospero et al. (2002) distinguish clearly two dust source areas affecting on the Arabian Peninsula: the first area is located in the valley between the Tigris and Euphrates rivers, where the mineral dust proceeds from the deserts of Iraq, northeast of Saudi Arabia and the south of Iran; and the second, close to the coast of Oman. Given the location of the selected stations in this region, these will be mainly affected by the first source area, especially Solar Village and Bahrain stations. In the latter station the highest aerosol amounts occur during summer, with an AOD of $0.4 \pm 0.2$, while in Sede Boker and Solar Village these maximal values are observed in spring, $0.2 \pm 0.2$ and $0.4 \pm 0.2$, respectively. In this season the multi-year regional maxima of AOD are also observed $(0.3 \pm 0.2)$ associated with the minima of $\eta(0.4 \pm 0.2)$, which confirms the mineral dust as the main aerosol source in the region during spring.

Finally, the locations in the region 4, R4, are distributed in the North of China (Sacol - SAC and Yulin - YUL) and in the interior region of Mongolia (Dalanzadgad - DAL), where several desert areas are located: the Taklamakan and the Gobi deserts and the arid regions in the interior plateau of Mongolia. These areas are responsible for the majority of Asian mineral dust episodes. Unlike the Taklamakan desert, where the production of mineral dust is almost constant throughout the entire year, the Gobi desert reveals a clear seasonal tendency (high emissions in spring and at the beginning of summer). These dust storms are directly related to the strong winds originated in Siberia (Prospero et al., 2002). This seasonality is clearly observed in the monthly evolution of the AOD and $\eta$ for this region (Figs. 2d and 3d). Although the AOD regional mean is lower in spring $(0.2 \pm 0.3)$ than summer $(0.3 \pm 0.3)$, the fine fraction values show larger aerosols during this time as it is to be expected under mineral dust conditions $(0.6 \pm 0.2$ and $0.7 \pm 0.2$ in spring and summer, respectively).

It is noteworthy to mention that AERONET retrieval models aerosol as a polydisperse mixture of randomly oriented spheroids (Dubovik et al., 2006). This allows accounting for desert dust particle non-sphericity. Correspondingly, the estimates $F^{\mathrm{A}}$ of radiation transformation by aerosol are also modeled using mixture of spheroids. Although, generally the radiation fluxes do not have much sensitivity to aerosol particle shape (see Mishchenko et al., 1997), Derimian et al. (2008) found that failure to account for desert dust particle non-sphericity leads to an overestimation of aerosol cooling effect by up to $10 \%$.

\subsection{Biomass burning}

Tropical regions $\left(25^{\circ} \mathrm{S}-25^{\circ} \mathrm{N}\right)$, during the dry season, are the main source areas of emissions of elemental and organic carbon to the atmosphere from the burning of forest biomass. These forest fires are associated with local and regional farming activities, where the lands are prepared for the crops in the wet season. Thus, from August to November, biomass burning takes place in the Amazonian forest, which makes up the region 5, R5, in this study (Abracos Hill - ABH, Alta Floresta - ALF, Balbina - BAL, Belterra - BEL, and Rio Branco - RIB). The biomass burning aerosols from the African savannah are included in the region 6, R6, (Mongu - MON, Skukuza - SKU, and Zambezi - ZAM), where this farming activity is also maintained until the end of the southern spring. Together with the production of biomass burning due to agriculture, biomass burning aerosols are also produced, but to a lesser extend, in forest fires in the continental platforms of North America and Eurasia. These fires occur almost exclusively during summer, when meteorological conditions are favorable for it. In order to study these contributions the region 7, R7, has been included and is made up of stations located in forested regions in North America (Thompson - THO, and Wasekiu - WAS).

As noted in the multi-year AOD annual cycles (Fig. 2e$\mathrm{g}$ ), the contribution of biomass burning particles is the only important source of aerosols in these three regions. Its seasonality is clearly distinguished: from August to November in the regions 5 and 6 (Fig. 2e and f, respectively), and during summer, from June to August, in the region 7 (Fig. 2g). The multi-year AOD average is $0.5 \pm 0.4$ in the dry season (August-November), while $0.1 \pm 0.1$ is found for the rest of the year in the region 5. The region 6 shows lower AOD averages: $0.3 \pm 0.2$ and $0.1 \pm 0.1$ during the dry and wet seasons respectively. These values significantly decrease in the region 7 , where the multi-year average is $0.2 \pm 0.2$ during summer (June-August) and $0.1 \pm 0.1$ during the rest of the year. Biomass burning aerosols are dominated by fine particles, so high values of the fine aerosol fraction are to be expected (between 0.7-1.0, Kaufman et al., 2005; García et al., 2011a). In fact, we found similar multi-year $\eta$ averages in the three regions: $0.8 \pm 0.1$.

\subsection{Urban-industrial}

The main sources of urban-industrial aerosols are found in the most heavily populated and industrialized areas of the world, such as the East and West coast of North America, Europe and Southeast Asia. Thus, the stations of the region 8, R8, (Lille - LIL, and Ispra - ISP), are located in significant urban-industrial areas of Europe, where the influence of anthropogenic aerosols is dominant. The same conditions are 
observed in the stations of the region 9, R9, which covers the US East Coast (Goddard Space Flight Center - GSF, Baltimore - BAL, and City College of New York city - CCN). Finally, the region 10, R10, includes stations located in eastern Asia (Anmyon - ANM, Gosan - GOS, NCU Taiwan TAW, Shirahama - SHI, and Beijing - BEI), where the urbanindustrial emissions are dominant during the entire year. Furthermore, there are notable episodes of mineral dust transport from the Gobi-Taklamakan deserts during spring and at the beginning of summer (e.g. Arimoto et al., 2006; García et al., 2009). The south-eastern region of Asia is especially significant because it reflects the growing industrial development of countries such as China.

As shown in Fig. $2 \mathrm{~h}$ the urban-industrial regions differ on AOD annual cycle. Two time periods (one warm, another cold) are revealed for both American and European regions, although with different duration. Thus, the region 8 shows the highest levels of AOD during the warmest months of the year, from March to September, $0.3 \pm 0.2$, while an AOD of $0.2 \pm 0.2$ is observed during the rest of the year. The region 9 also presents maxima during the warm season, although they are limited to the summer months (AOD average of $0.3 \pm 0.3$ from June to August). The AOD annual cycle observed in these regions is attributed to the typical meteorological patterns found in the mid-latitudes. During winter the particle levels are lower due to the increase of the wet deposition processes, while in the warm season the anti-cyclonic conditions allow to greater residence time of aerosols in the atmosphere and phenomena of stagnant air masses (e.g. Holben et al., 2001).

Like biomass burning aerosols, the urban-industrial ones are characterized by very small particles, so the fine mode is predominant in the particle size distribution (see Fig. 3h). The multi-year $\eta$ average is $0.9 \pm 0.1$ in the region 8 and $0.9 \pm 0.1$ in the region 9 , values very close to those found under biomass burning aerosols (Sect. 3.2).

In all stations of the region 10 the contribution of desert mineral dust is clearly distinguished from March to May, since an increase in the AOD regional average $(0.5 \pm 0.4)$ is associated with a marked decrease of the aerosol fine fraction at $0.55 \mu \mathrm{m}$ (see Figs. $2 \mathrm{i}$ and $3 \mathrm{i}$ ). Even though the $\eta$ values observed during the spring correspond to the annual minimum $(0.6 \pm 0.2)$, they are still greater than those registered under the influence of "pure" mineral dust, $\sim 0.2-0.4$ in R2 in spring (see Fig. 3a), showing a mixture of mineral dust and regional pollution. The aerosol levels start to fall from July, coinciding with the beginning of the wet Asiatic monsoon season, and reach the minimum values during autumn and winter (AOD $=0.4 \pm 0.4$ and $\eta=0.8 \pm 0.1)$. Note that during summer the $\eta$ values are of the order to those associated with the presence of small aerosols such as pure urban-industrial or biomass burning particles, between 0.7-1.0.

\subsection{Continental background}

Regarding aerosols from the continental background, two groups appear: the region 11, R11, made up of European locations, Toravere - TOR and Yekaterinburg - YEK, and the region 12, R12, with stations located in North America: Bratts Lake - BRL, Saturn Island - SAI and Sevilleta - SEV. These sites are found in non-industrial areas located in the American and eastern European prairies, where the main aerosol type generally proceeds from continental background.

The presence of local anthropogenic pollution sources is not significant in these regions (Holben et al., 2001; McArthur et al., 2003; Russak et al., 2007) and, as a result, aerosol levels are relatively low throughout the year (Fig. 2j). multi-year AOD averages of $0.2 \pm 0.2$ and $0.1 \pm 0.1$ are observed in the region 11 and 12 respectively, whereby we may assume that the continental European background is under a greater contribution of aerosols than the American one.

In the region 11 there are only measurements during the warmest months (from March to September) due to the meteorological conditions in the region. Considering this fact, the highest AOD values are found during summer, $0.2 \pm 0.2$ in contrast to $0.1 \pm 0.1$ during spring. Although a large variability in the AOD is noticeable throughout the entire year in the two stations of this region (the standard deviation is between 0.1 and 0.3). Furthermore, the increase of $\eta$ in summer $(0.9 \pm 0.1)$ with regard to the spring values $(0.8 \pm 0.1)$ confirms the presence of smaller particles. In the region 12 , the highest AOD and $\eta$ values are also observed in summer $(0.1 \pm 0.1$ and $0.8 \pm 0.1$, respectively). Thus, these stations may be affected by the presence of external contributions such as those originated by forest fires or the transregional pollution transport, especially in summer (Russak et al., 2007). Therefore, to avoid these possible external contributions the spring measurements will be considered in the following analysis, when the continental background conditions prevail in both regions.

\subsection{Oceanic aerosols}

Region 13, R13, is made up of oceanic stations, influenced by maritime aerosols, located in the Atlantic Ocean (Bermuda - BER) and the Pacific Ocean (Lanai - LAN, and Nauru NAU). Even though there are differences between the microphysical and radiative properties of the aerosols in the two oceans (Smirnov et al., 2002), they have been grouped together because of the reduced number of stations in relatively pure oceanic conditions. These differences are mainly due to there being more sources of aerosols affecting the Atlantic Ocean than the Pacific besides the different aerosol emissions. The stations located in the Atlantic Ocean may be influenced by urban-industrial aerosols from North America and Europe, desert mineral dust from the Sahara-Sahel regions and biomass burning from South America, West and 
Southern Africa, while the stations in the Pacific Ocean may be affected by Asian aerosols (mineral dust, urban-industrial and biomass burning) together with the pollutant emissions from Central America.

The multi-year AOD average for the Atlantic station is $0.1 \pm 0.1$, (Fig. $2 \mathrm{k}$ ), doubling the values obtained for the Pacific sites: $0.06 \pm 0.03$ and $0.05 \pm 0.02$ for Lanai and Nauru, respectively. In these last two cases, the aerosol levels only deviate from these averages during the spring, where the transoceanic transport of Asian mineral dust may occasionally increase them, in particular for the Lanai station (Holben et al., 2001; Smirnov et al., 2002). Also, notice that the island of Lanai belongs to the Hawaiian archipelago and, like Mauna Loa station, can also be affected by sporadic emissions from volcanic aerosols (Holben et al., 2001). As seen in Fig. 2k, the aerosol levels are more stable during autumn and winter, reaching their annual minimum values during these seasons for the three stations. Hence, oceanic aerosols may be well represented by autumn and winter periods. Note that the AOD and $\eta$ regional annual cycles were not calculated for oceanic and free troposphere regions (Fig. $2 \mathrm{k}$ and $\mathrm{l}$ and Fig. 3k and 1), since their stations are in different oceans.

\subsection{Free troposphere}

The stations from region 14, R14, Mauna Loa - MLO and Izaña - IZO observatories, are located at a high altitude (2367 and $3397 \mathrm{~m}$ a.s.l. IZO and MLO, respectively) and above a thermal inversion layer, hence avoiding vertical transports and possible mixture processes with local pollution. They are characterized by conditions of low turbidity and almost clear atmosphere, allowing us to evaluate radiative forcing of global background.

In both cases the contributions of natural and anthropogenic aerosols are reduced, as can be observed in Fig. 21. The exceptions are episodes of African desert mineral dust measured in Izaña during the warmest months (from June to October). An AOD average of $0.1 \pm 0.1$ is obtained in this time period in contrast to $0.02 \pm 0.01$ recorded during the rest of the year, which approaches the multi-year AOD mean of MLO, $0.04 \pm 0.01$. This seasonality is governed by the regional meteorological conditions (Azores High and North African Low), which also affect the regions 1 and 2 (Díaz et al., 2006; García et al., 2009). Therefore, the winter can be considered as representative of free troposphere conditions (AOD season mean of $0.03 \pm 0.02$ ) to estimate the aerosol radiative forcing in this region.

\section{Results and discussion}

\subsection{Influence of the surface albedo}

The influence of the surface albedo (SA) on the aerosol radiative forcing is clearly observed by comparing the $\Delta F$ averages at the TOA for each surface albedo interval (Fig. 4). As shown in this figure for the regions influenced by desert mineral dust (R1, R2, R3 and R4), urban-industrial aerosols (R8, $\mathrm{R} 9$ and R10) and continental background (R11 and R12), the sign of the $\Delta F$ changes, and consequently the net radiative effect of aerosols, as the SA increases. Besides the cases with sza between $55-65^{\circ}$, we have also included in this figure the whole sza range of AERONET $\Delta F$ estimates $\left(<55^{\circ}, 65-75^{\circ}\right.$ and $>75^{\circ}$ ) to document better the change of sign of the $\Delta F$. In order to make this comparison, and hereafter, we consider a unique value of the spectral SA for each almucantar retrieval. As aforementioned, this representative value, used to define the SA ranges and to estimate the $\Delta F$ at the BOA, is obtained from the spectral average of the surface albedo calculated by V2 AERONET algorithm at $0.44,0.67,0.87$ and $1.02 \mu \mathrm{m}$. These values are representative of oceanic surfaces and those with vegetation $(<0.18-0.20)$, desert regions $(0.20-0.50)$ and areas covered by ice or snow $(>0.50)$.

As shown in the radiative forcing at the TOA for darkest surfaces, $\mathrm{SA}<0.30$, aerosols cool the atmospheric column for all regions, independent of the aerosol type (mineral dust, urban-industrial or continental background). Nonetheless, for the intermediate range, $0.30<\mathrm{SA}<0.50$ in desert dust regions, positive and negative values of $\Delta F$ are observed depending on the region and the aerosol type $(\Delta F \geq 0$, in this surface albedo interval, represent around $35 \%$ of total data in these regions for sza between $55-65^{\circ}$ ). Under these situations the sign of radiative forcing mainly depends on two factors, the size distribution and the aerosol mineralogical composition, which determine the aerosol single scattering albedo, $\omega$. For example, García et al. (2011a) found that the change of sign of the $\Delta F$ is around $\omega(0.55 \mu \mathrm{m})<0.88$ in R2. Thus, $\omega$ $(0.55 \mu \mathrm{m})<0.88$ lead to a warming of the Earth-atmosphere system, with $\Delta F$ of $10 \pm 11 \mathrm{Wm}^{-2}$ for the mixture of mineral dust and biomass burning in $\mathrm{R} 2$ in winter, while a value of $28 \pm 16 \mathrm{Wm}^{-2}$ is found under the presence of pure mineral dust during the spring for sza between $50-80^{\circ}$. Although the net effect of pure mineral dust is more noticeable, the biomass burning particles enhances the absorption capacity of mineral dust. Thus, the number of cases for the mixture situations (R2 in winter), where $\omega(0.55 \mu \mathrm{m})<0.88$, triplicates those recorded under only mineral dust (R2 in spring). However, it should be mentioned that despite instantaneous forcing for high sun elevation can present positive values, for low sun it can remained negative therefore the daily average forcing can still be negative. Anyway, in these situations, aerosols cooling effect is significantly reduced and they do not strongly counteract the warming effect of the greenhouse gases.

Finally, for snow covers (SA $>0.50$ in mineral dust regions and $\mathrm{SA}>0.30$ in urban-industrial and continental background regions), positive $\Delta F$ values are normally observed, leading a warming of climatic system regardless of aerosol type. For mineral dust these cases were only observed for the stations of R4 during the winter months, making up $2 \%$ of the total group in this region (sza between $55-65^{\circ}$ ). 

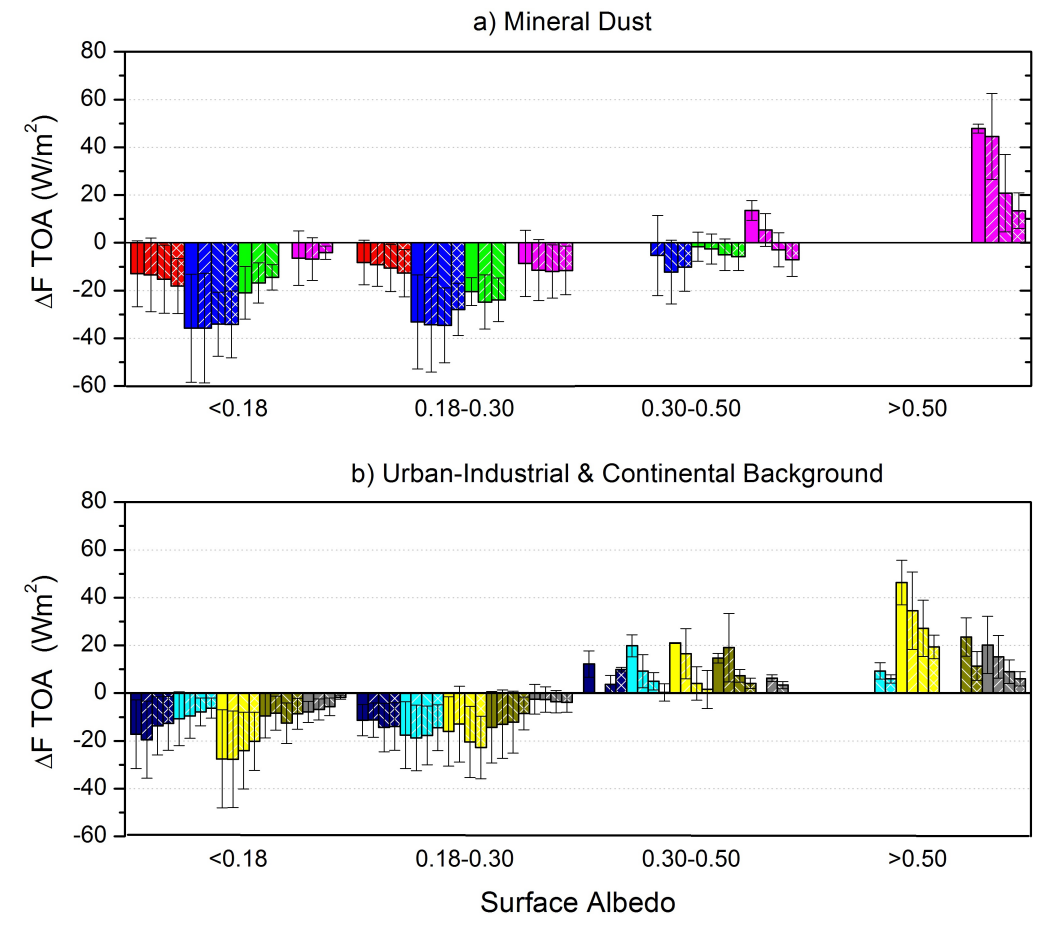

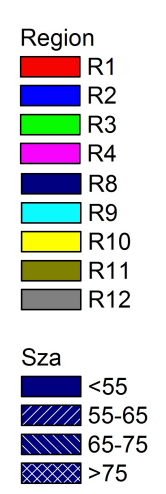

Fig. 4. Multi-year average of aerosol radiative forcing, $\Delta F\left(\mathrm{Wm}^{-2}\right)$, at the TOA for the regions influenced by (a) desert mineral dust (R1, R2, R3 and R4) and (b) urban-industrial and continental background aerosols (R8, R9, R10, R11 and R12) for each interval of surface albedo $(<0.18,0.18-0.30,0.30-0.50$ and $>0.50)$ and of solar zenith angle $\left(<55^{\circ}, 55-65^{\circ}, 65-75^{\circ},>75^{\circ}\right)$. Error bars indicate $\pm 1 \sigma(\sigma$, standard deviation).

Under urban-industrial aerosols they represent around $1 \%$, while in the continental background regions they reach $7 \%$ and $2 \%$ in the R11 and R12 respectively (sza between 55$65^{\circ}$.

In the light of the above results, the effect of surface albedo on the $\Delta F$ is critical for $\mathrm{SA}>0.30$, but not for $\mathrm{SA}<0.30$. Therefore, the $\Delta F$ has been analyzed for all aerosol regimes considering three SA ranges: $0-0.30,0.30-0.50$ and $>0.50$. Note that cases with $\mathrm{SA}>0.30$, in the seasons representative of key aerosol types, are only observed for mineral dust and continental background aerosols.

\subsection{Radiative forcing at the BOA and the TOA}

In order to make a consistent comparison between the radiative effects of key aerosol types, the $\Delta F$ values at the BOA and the TOA have only been compared for sza between 55$65^{\circ}$ and for those seasons where each aerosol type is predominant in each region, according to the description of the sites given in Sect. 3. Thus, for the regions affected by mineral dust we have selected the summer values in the region 1 (R1-J), and the spring ones in the regions 2, 3 and 4 (R2-M, R3-M and R4-M). Regarding biomass burning aerosols, autumn in the regions 5 and 6 (R5-S and R6-S), and summer in the region 7 (R7-J) were considered. In urban-industrial environments, regions 8,9 and 10 , summer was used as ref- erence (R8-J, R9-J and R10-J), while spring for the continental background (R11-M and R12-M). Winter was selected for the oceanic aerosols (R13-S) and for the free troposphere region (R14-D). Finally, in order to study the influence of the mixture of aerosols winter was included in the region 2 , with the presence of mineral dust and biomass burning particles (R2-D), and spring in the region 10 with urban-industrial aerosols and mineral dust (R10-M). The regional multi-year averages of AOD and $\omega$ at $0.55 \mu \mathrm{m}$ for the seasons selected in each region is shown in the Fig. 5. The $\omega$ at $0.55 \mu \mathrm{m}$ is obtained by linearly interpolating the $\omega$ at the AERONET wavelengths $0.44 \mu \mathrm{m}$ and $0.67 \mu \mathrm{m}$. Note that these averages for the mineral dust and continental background regions (R1, R2, R3, R4, R11 and R12) were evaluated for each surface albedo range. As aforementioned, the discussion of the radiative forcing should be separated for each surface albedo range. Thus, for $\mathrm{SA}<0.30$, the $\Delta F$ multi-year averages were negative in all regions both at the BOA and the TOA, implying an aerosol cooling effect according to the sign criterion used for the $\Delta F$ as shown in Fig. 6. The maximal values of $\Delta F$ at the surface (see Fig. 6.a) are found in the West Africa region during winter (R2-D), associated with the mixture of mineral dust from the Sahara-Sahel desert and biomass burning aerosols, $-122 \pm 37 \mathrm{Wm}^{-2}$ $(\mathrm{AOD}=0.85 \pm 0.45)$, together with spring $(\mathrm{R} 2-\mathrm{M})$, where mineral dust is the dominant aerosol: $\Delta F=-91 \pm 36 \mathrm{Wm}^{-2}$ 

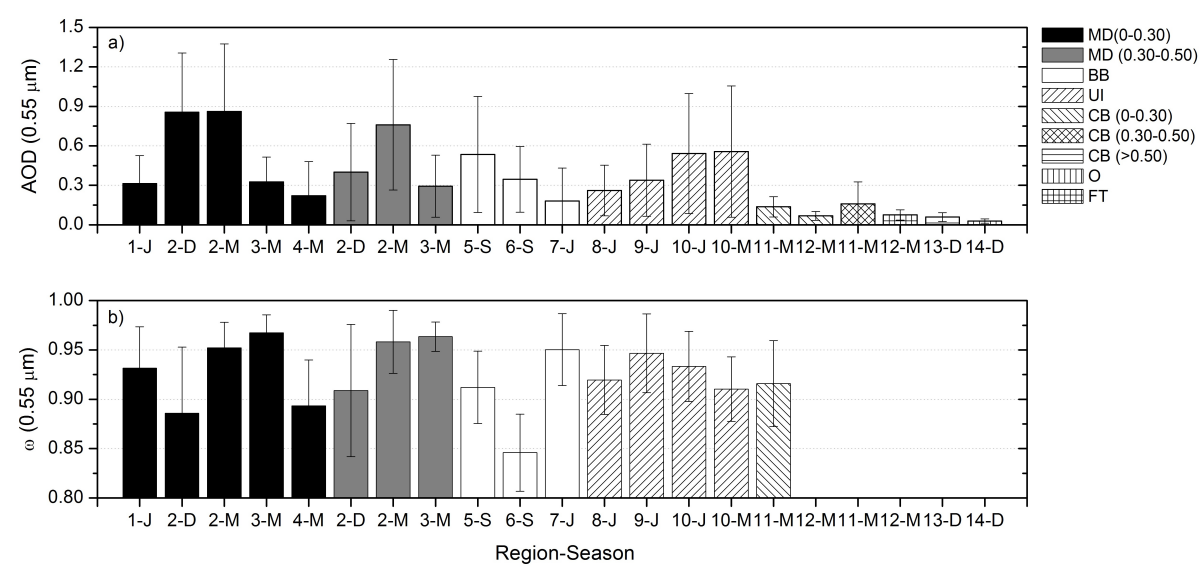

Fig. 5. Multi-year average of aerosol optical depth, AOD, at $0.55 \mu \mathrm{m}$ (a), and single scattering albedo, $\omega$, at $0.55 \mu \mathrm{m}$ (b), for each region and season. $\mathrm{M}=$ March-April-May, $\mathrm{J}=$ June-July-August, $\mathrm{S}=$ September-October-November and $\mathrm{D}=$ December-January-February. The legend shows each aerosol type: $\mathrm{MD}=$ Mineral Dust, $\mathrm{BB}=$ Biomass Burning, UI $=$ Urban-Industrial, $\mathrm{CB}=\mathrm{Continental} \mathrm{Background}, \mathrm{O}=\mathrm{Oceanic}$ and FT $=$ Free Troposphere. For the regions influenced by desert mineral dust and continental background, the AOD and $\omega$ averages have been evaluated for each interval of surface albedo (SA): $0-0.30,0.30-0.50$ and $>0.50$. Error bars indicate $\pm 1 \sigma$ ( $\sigma$, standard deviation).
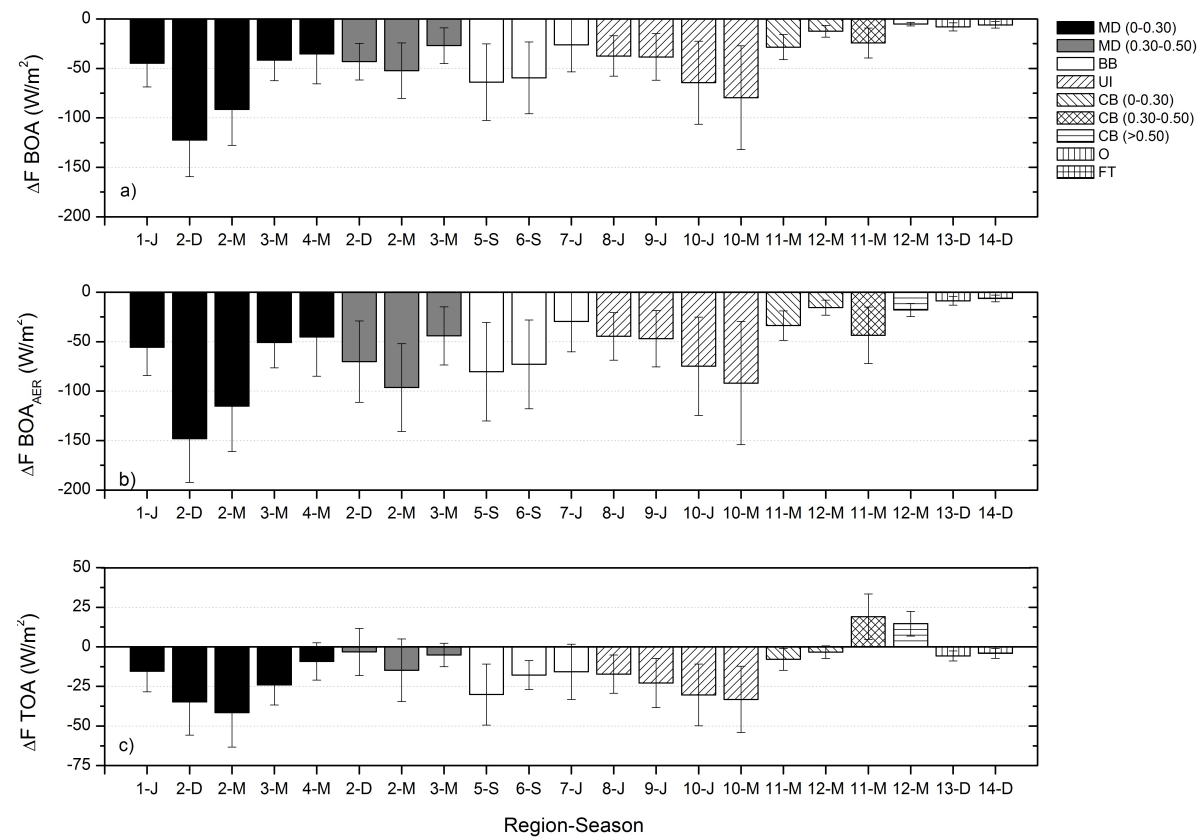

Fig. 6. Multi-year average of the aerosol radiative forcing, $\Delta F\left(\mathrm{Wm}^{-2}\right)$, at the BOA (Eq. 3) (a), AERONET $\Delta F$ BOA AER at the BOA (Eq. 5) (b), and $\Delta F$ at the TOA (Eq. 2) (c) for each region and season. The seasons and aerosol types are labeled as Fig. 5. Error bars indicate $\pm 1 \sigma$ ( $\sigma$, standard deviation).

$(\mathrm{AOD}=0.86 \pm 0.51)$. In this region we also found the highest AOD levels among those analyzed. Next, the Asiatic urbanindustrial region shows the largest values: $-80 \pm 52 \mathrm{Wm}^{-2}$ $(\mathrm{AOD}=0.56 \pm 0.50)$ during spring $(\mathrm{R} 10-\mathrm{M})$, under the influence of urban-industrial aerosols mixed with desert mineral dust, and $-64 \pm 42 \mathrm{Wm}^{-2}$ ( $\left.\mathrm{AOD}=0.54 \pm 0.46\right)$ during summer (R10-J), only with urban-industrial particles. The latter is quite similar to the $\Delta F$ values observed for the biomass burning regions from South America and South- ern Africa during autumn (R5-S and R6-S), period of maximal activity. In these regions, the $\Delta F$ reaches $-64 \pm 39$ and $-60 \pm 36 \mathrm{Wm}^{-2}$ for an AOD average of $0.53 \pm 0.44$ and $0.35 \pm 0.25$, respectively. These values are slightly higher than the $\Delta F$ obtained in desert mineral dust regions, such as North Africa (R1-J) or the Arabian Peninsula (R3-M), and the urban-industrial regions from Europe (R8-J) and North America (R9-J), where the $\Delta F$ is approximately $-45 \mathrm{Wm}^{-2}$ for an AOD of $\sim 0.3$. Regarding 

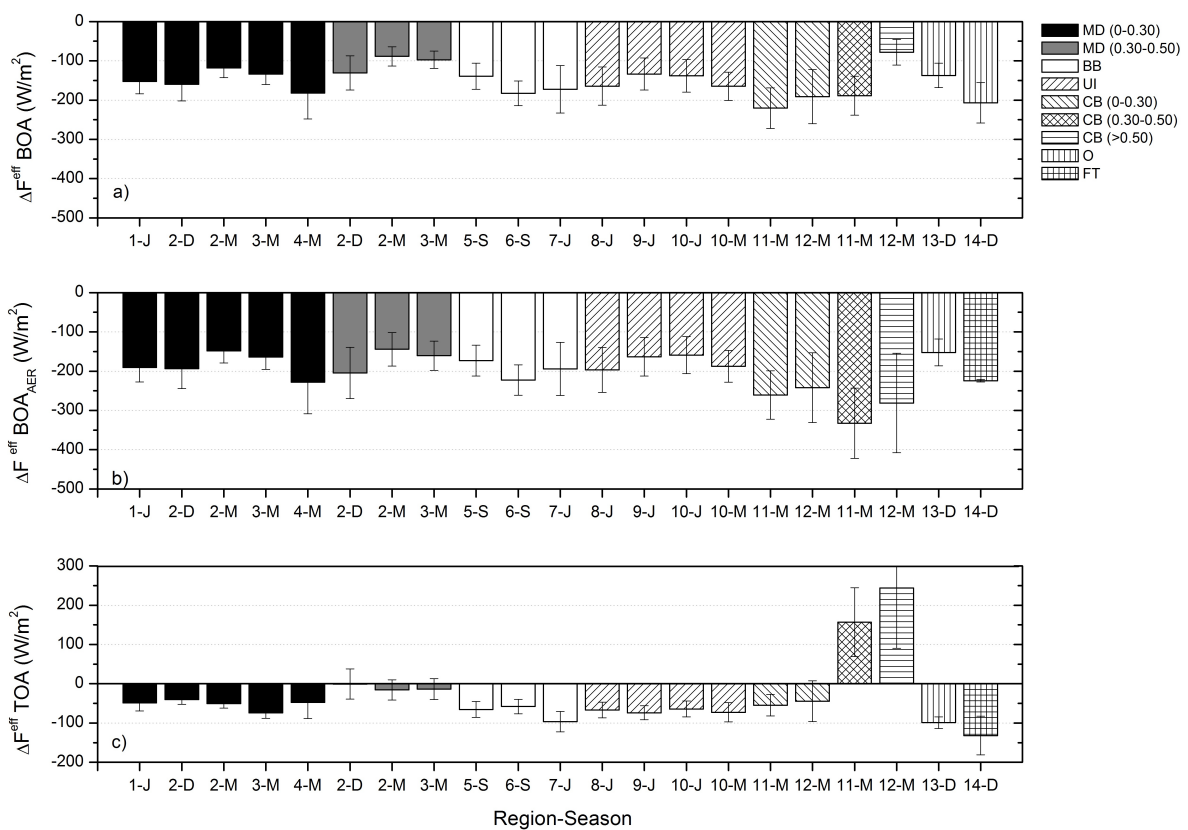

Fig. 7. Multi-year average of the radiative forcing efficiency, $\Delta F^{\mathrm{eff}}\left(\mathrm{Wm}^{-2}\right)$, at the BOA (a), AERONET $\Delta F^{\text {eff }}$ BOA AER at the BOA (b), and $\Delta F^{\text {eff }}$ at the TOA (c) for each region and season. The seasons and aerosol types are labeled as Fig. 5. Error bars indicate $\pm 1 \sigma(\sigma$, standard deviation).

continental background aerosols, $\Delta F$ values in the European region (R11-M) double those observed in the American region (R12-M). Thus, during spring the $\Delta F$ average is $-29 \pm 13 \mathrm{Wm}^{-2}(\mathrm{AOD}=0.14 \pm 0.08)$ in $\mathrm{R} 11$ in contrast to $-12 \pm 6 \mathrm{Wm}^{-2}(\mathrm{AOD}=0.07 \pm 0.03)$ in R12. Finally, in the oceanic and free troposphere regions radiative forcing lower than $-10 \mathrm{Wm}^{-2}$ were obtained for AOD $<0.1$, which are the lowest values obtained.

Note that operational AERONET $\Delta F$ values at the BOA $\left(\triangle F \mathrm{BOA}_{\mathrm{AER}}\right.$, see Fig. $6 \mathrm{~b}$ ) properly follow the behavior described for $\Delta F$. As aforementioned, we observe an overestimation of the real $\Delta F$, which is more marked for the brightest surfaces: continental background regions under snow conditions (R11-M and R12-M for SA > 0.30) and desert regions (R2-D, R2-M and R3-M for SA > 0.30).

At the TOA the differences between aerosols and regions are less significant. The maximum values of $\Delta F$ are also observed in the West Africa region: $-42 \pm 22 \mathrm{Wm}^{-2}(\mathrm{R} 2-\mathrm{M})$ and $-35 \pm 21 \mathrm{Wm}^{-2}$ (R2-D) for SA $<0.30$. They are comparable to those recorded in the biomass burning regions from South America, $-30 \pm 19 \mathrm{Wm}^{-2}$ (R5-S) and Asian urban-industrial aerosols, $-33 \pm 21 \mathrm{Wm}^{-2}$ (R10-M). As at the BOA, the $\Delta F$ values at the TOA due to the European continental background double those observed in the American region: $-8 \pm 7 \mathrm{Wm}^{-2}$ and $-3 \pm 4 \mathrm{Wm}^{-2}$, respectively. Oceanic aerosols and in conditions of free troposphere are the lowest of those analyzed, $<-10 \mathrm{Wm}^{-2}$, although they are comparable to other regions (Fig. 6b), especially with high surface reflectivity (e.g. R2-D or R3-M).
Considering the influence of the surface albedo on the aerosol radiative forcing is essential, since the $\Delta F$ absolute values notably decrease as SA increases and even a change of sign in the $\Delta F$ can be observed. Notice, for example, the positive $\Delta F$ averages of the region 11 and 12 for $\mathrm{SA}>0.30$ or as the $\Delta F$ averages of the region $\mathrm{R} 2-\mathrm{D}, \mathrm{R} 2-\mathrm{M}$ and $\mathrm{R} 3-\mathrm{M}$ at the TOA for SA $>0.30$ are comparable to the background continental, oceanic or free troposphere regions, even though the AOD averages are notably lower. Nonetheless, its effect is more evident in analyzing the radiative forcing efficiency, as seen in the following section (Sect. 4.3).

\subsection{Radiative forcing efficiency at the $\mathrm{BOA}$ and the TOA}

The aerosol radiative forcing efficiency is a useful tool to compare aerosol types, since it is not dependent on AOD. Hence, the influence of other factors such as absorbing and scattering aerosol properties or surface albedo may become more evident. Nonetheless, when analyzing the efficiency values it is necessary to take their moderation for high AOD into account, i.e. the increase of the efficiency for AOD $\ll 1$ (Conant et al., 2003). This fact is due to the increase of multiple scattering effects and attenuation of the transmitted radiation for large AOD. The free tropospheric aerosols are a clear example of this artefact, where higher values of $\Delta F^{\mathrm{eff}}$ (in absolute terms, see Fig. 7) were observed associated with the lowest AOD range (Fig. 5a). These $\Delta F^{\text {eff }}$ values are higher than those ones found for aerosols with higher capacity of 
extinguishing the solar energy, such as the mineral dust or the biomass burning aerosols. This artefact may also be responsible in part to the higher $\Delta F^{\mathrm{eff}}$ averages observed for background continental regions (R11 and R12) or oceanic conditions (R13). At the same time, it should be mentioned that even not significant uncertainties in the absolute values of radiative forcing at the low AOD can present more significant impact on relative to AOD values of forcing efficiency.

As in the radiative forcing analysis, the discussion of the efficiency should be separated for each surface albedo range in order to examine better the influence of aerosol characteristics and properties. Thus, for $\mathrm{SA}<0.30$ and except for the aforementioned regions (background continental, oceanic and free troposphere), the aerosols more efficient at the surface are overall the more absorbing aerosols (see Fig. 7.a), such as the biomass burning particles from the African savannah (R6-S), where we observed a $\Delta F^{\text {eff }}$ of $-183 \pm 31 \mathrm{Wm}^{-2}$. In general, we observed $\Delta F^{\text {eff }}$ averages around $-160-170 \mathrm{Wm}^{-2}$ for those regions and seasons with $\omega(0.55 \mu \mathrm{m})<0.93-0.95$ (e.g. R1-J, R2-D, R4-M, R7-J, see Fig. $5 b)$. In the rest of cases, where $\omega(0.55 \mu \mathrm{m})>0.93-$ 0.95 (e.g. R2-M or R3-M), the $\Delta F^{\text {eff }}$ averages are around $-125 \mathrm{Wm}^{-2}$.

At the TOA the contrary behavior is documented: the more absorbing aerosols show the lower $\Delta F^{\text {eff }}$ averages like R6-S or R2-D. This fact is due to the higher absorption of these aerosols reduces the energy available to be backscattered towards the upper limit of the atmosphere and into the space, maintaining a higher percentage of solar energy in the atmosphere.

For each aerosol type, the biomass burning aerosols are a clear example of the aforementioned. Although the aerosol levels are lower in the African savannah (R6) than in the Amazon region (R5) during the burning season, the $\Delta F^{\text {eff }}$ values do not follow this trend, since the African region shows greater absorption capacity: $\omega$ average of $0.91 \pm 0.04$ in R5-S in contrast to $0.85 \pm 0.04$ in R6-S. The differences in the radiative properties between the regions 5 and 6 is attributable to the different composition of combustible material and different associated combustion processes (combustion with or without flames). In African savannah most of biomass burning particles is produced by flaming combustion, while in the deforestation fires, typical of the Amazon forest, $\sim 50 \%$ or less of the biomass burning is produced by this phase of combustion (Eck et al., 2001 and references therein). These different production mechanisms lead to different concentration of black carbon: $15-20 \%$ of the aerosol generated during the flaming combustion phase corresponds to black carbon, while less than $3 \%$ during the smoldering combustion (Ward et al., 1992, 1996). Therefore, biomass burning aerosols in the Amazonian savannah are more efficient than African ones at the TOA (a $22 \%$ on average, Fig. $6 \mathrm{c}$ and d), while the opposite occurs at the BOA, where $\mathrm{R} 5$ is a $12 \%$ less efficient than R6. Regarding the boreal forest (R7) the high $\omega$ values are mainly due to processes of smoldering combustion (Dubovik et al., 2002a). Therefore, the radiative forcing efficiency in this region is significantly higher at the TOA than those obtained in the regions 5 and 6 .

Similar behavior was observed under pure urban-industrial environments (R8-J, R9-J and R10-J). The urban-industrial region in Europe reveals more efficient aerosols at the BOA, with a $\Delta F^{\text {eff }}$ of about $-165 \mathrm{Wm}^{-2}$, and slightly higher than those observed in the American and Asiatic regions $\left(\sim-135 \mathrm{Wm}^{-2}\right)$. At the TOA, the differences in the radiative effect are not so noticeable in the three regions, $\Delta F^{\text {eff }}$ $\sim-70 \mathrm{Wm}^{-2}(\mathrm{SA}<0.30)$. After biomass burning aerosols, urban-industrial particles have the most important absorption properties in the range $0.44-1.02 \mu \mathrm{m}$. Thus, comparing with the main regions of biomass burning, R5 and R6, the urbanindustrial and biomass burning aerosols show similar $\Delta F^{\text {eff }}$ values at the TOA and lower values at the BOA, resulting on average the same energy stored in the atmosphere.

In the case of pure mineral dust (R1-J, R2-M, R3-M and R4-M), we observe that African mineral dust from R1 and Asian dust from R4 are the most efficient at the BOA, associated with the lowest $\omega$. In these regions mineral dust particles may be mixed with local and long-transport pollution, which enhance the absorption capacity of mineral dust (Díaz et al., 2006; Arimoto et al., 2006; Rodríguez et al., 2011). Note that, for example for the African mineral dust, R1 shows mineral dust more efficient at the BOA than R2-M, while at the TOA the differences are not so significant.

The influence of surface reflectivity on $\Delta F$ and $\Delta F^{\text {eff }}$ is observed by comparing the $\Delta F^{\text {eff }}$ values at the TOA for different SA intervals in the regions affected by mineral dust (R2-D, R2-M and R3-M, see Fig. 6d). We find reductions of the absolute values of the $\Delta F^{\text {eff }}$, on average, of $70 \%$ (R2M), $81 \%$ (R3-M) and $98 \%$ (R2-D) for the largest surface albedo range, which lead even positive values of $\Delta F^{\mathrm{eff}}$ in all of the three regions. Note that the more significant decrease of the $\Delta F^{\mathrm{eff}}$ is observed for the region with the most absorbing aerosols (R2-D). The albedo surface influence is also clearly documented in the continental background regions. This behavior, as the surface albedo increases, is due to that the backscattered energy towards the top of atmosphere increases faster in clear conditions than under the presence of aerosols, because it is not affected by aerosol scattering and absorption processes. These effects are more evident at the TOA than at the BOA, although visible in both cases.

\section{Conclusions}

In recent years there has been a considerable effort to reduce the uncertainties in the radiative effect of atmospheric aerosols. Improving our knowledge about aerosol effects is essential for understanding Earth's climate. However, it is quite difficult to compare directly the obtained results on literature due to the different methodologies and data used. Thus, this work had presented valuable information allowing 
the inter-comparison of the direct radiative effect of the main types of aerosols in similar observational conditions (that mainly means similar solar zenith angles). In this context, AERONET network has shown to be a very useful tool for monitoring the instantaneous aerosol radiative forcing and the radiative forcing efficiency. The high density of the AERONET stations allows a detailed analysis of aerosol radiative forcing for different aerosol conditions, from anthropogenic to free troposphere conditions.

In general, the aerosols analyzed have confirmed their tendency of cooling of Earth-atmosphere system. Based on aerosol amounts and on darkest surfaces, the most effective particles to cool the climatic system (radiative effect at the top of atmosphere) are the least absorbing aerosols such as the mineral dust from Arabian Peninsula desert areas, biomass burning particles from boreal forest and urbanindustrial aerosols combined with desert mineral dust in the Asian region. Nonetheless, special attention should be paid to aerosol emissions and their transport in highly reflective areas (deserts or snow) by their warming effect. In these cases there is more solar energy available for favoring unequal warming of atmosphere, modifying the clouds characteristics and contributing to the warming effect of greenhouse gases.

Improving our knowledge about the direct radiative effects of atmospheric aerosols is a necessary step in order to address the indirect and semi-direct aerosol effects and, thus, the consequences of the transformation of the solar energy stored by aerosols in the atmosphere. In this sense, AERONET provides a very valuable information about the geographical distribution of the most sensitive areas to an unequal effect of atmospheric aerosols.

Acknowledgements. We acknowledge to the MEC (Ministry of Education and Science, Spain) for the next supports: projects CGL2007-66477-C02-02/CLI, CGL2008-04740/CLI and CGL2010-21366-C04-01. We gratefully acknowledge the data provided by AERONET network and we wish to express our appreciation to the operators of stations for theirs helps on running the instruments.

Edited by: M. King

\section{References}

Ackerman, A. S., Toon, O. B., Stevens, D. E., Heymsfield, A. J., Ramanathan, V., and Welton, E. J.: Reduction of tropical cloudiness by soot, Science, 288, 1042-1047, 2000.

Arimoto, R., Kim, Y. P., Quinn, P., Bates, T., Anderson, T., Gong, S., Uno, I., Chin, M., Huebert, B., Clarke, A., Shinozuka, Y., Weber, R., Anderson, J., Guazzotti, S., Sullivan, R., Sodeman, D., Prather, K., and Sokolik, I.: Characterization of Asian Dust during ACE-Asia, Global Planet. Change, 52, 23-56, 2006.
Charlson, R. J., Lovelock, J. E., Andreae, M. O., and Warren, S. G.: Oceanic phytoplankton, atmospheric sulphur, cloud albedo and climate, Nature, 326, 655-661, 1987.

Conant, W., Seinfeld, J., Wang, J., Carmichael, G., Tang, Y., Uno, I., Flatau, P., Markowicz, K., and Quinn, P.: A model for the radiative forcing during ACE-Asia derived from CIRPAS Twin Otter and R/V Ronald H. Brown data and comparison with observations, J. Geophys. Res., 108, 8661, doi:10.1029/2002JD003260, 2003.

Cox, C. and Munk, W.: The measurements of the roughness of the sea surface from photographs of the Sun's glitter, J. Opt. Soc. Am., 44, 838-850, 1954.

Derimian, Y., León, J.-F., Dubovik, O., Chiapello, I., Tanré, D., Sinyuk, A., Auriol, F., Podvin, T., Brogniez, G., and Holben, B. N.: Radiative properties of aerosol mixture observed during the dry season 2006 over M'Bour, Senegal (African Monsoon Multidisciplinary Analysis campaign), J. Geophys. Res., 113, D00C09, doi:10.1029/2008JD009904, 2008.

Díaz, J., Expósito, F., Torres, C., Herrera, F., Prospero, J., and Romero, M.: Radiative properties of aerosols in Saharan dust outbreaks using ground-bsed and satellite data: Applications to radiative forcing, J. Geophys. Res., 106, 18403-18416, 2001.

Díaz, A., Díaz, J., Expósito, F., Hernández-Leal, P., Savoie, D., and Querol, X.: Air masses and aerosols chemical components in the free troposphere at the subtropical Northeast Atlantic region, J. Atmos. Chem., 53, 63-90, 2006.

Dubovik, O. and King, M. D.: A flexible inversion algorithm for retrieval of aerosol optical properties from sun and sky radiance measurements, J. Geophys. Res., 105, 20673-20696, 2000.

Dubovik, O., Smirnov, A., Holben, B. N., King, M. D., Kaufman, Y. J., Eck, T. F., and Slutsker, I.: Accuracy assessment of aerosol optical properties retrieval from AERONET sun and sky radiance measurements, J. Geophys. Res., 105, 9791-9806, 2000.

Dubovik, O., Holben, B. N., Eck, T. F., Smirnov, A., Kaufman, Y. J., King, M. D., Tanré, D., and Sluster, I.: Variability of absorption and optical properties of key aerosol types observed in worlwide locations, J. Atmos. Sci., 59, 590-608, 2002a.

Dubovik, O., Holben, B. N., Lapyonok, T., Sinyuk, A., Mishenko, M. I., and Slustker, I.: Non-spherical aerosol retrieval method employing light scattering by spheroids, Geophys. Res. Lett., 29, 1415, doi:10.1029/2001GL014506, 2002b.

Dubovik, O., Sinyuk, A., Lapyonok, T., Holben, B. N., Mishchenko, M., Yang, P., Eck, T. F., Volten, H., Munoz, O., Veihelmann, B., van der Zande, W. J., Leon, J.-F., Sorokin, M., and Slutsker, I.: Application of light scattering by spheroids for accounting for particle non-sphericity in remote sensing of desert dust, J. Geophys. Res., 111, D11208, doi:10.1029/2005JD006619, 2006.

Dubovik, O., Herman, M., Holdak, A., Lapyonok, T., Tanré, D., Deuzé, J. L., Ducos, F., Sinyuk, A., and Lopatin, A.: Statistically optimized inversion algorithm for enhanced retrieval of aerosol properties from spectral multi-angle polarimetric satellite observations, Atmos. Meas. Tech., 4, 975-1018, doi:10.5194/amt-4975-2011, 2011.

Dubuisson, P., Buriez, J. C., and Fouquart, Y.: High spectral resolution solar radiative transfer in absorbing and scattering media, appliation to the sattelite simulations, J. Quant. Spectrosc. Ra., 55, 103-126, 1996.

Dubuisson, P., Dessailly, D., Vesperini, M., and Frouin, R.: Water vapor retrieval over ocean using near-infrared imagery, J. 
Geophys. Res., 109, D19106, doi:10.1029/2004JD004516, 2004.

Dubuisson, P., Roger, J.-C., Mallet, M., and Dubovik, O.: A code to compute the direct solar radiative forcing: application to anthropogenic aerosols during the ESCOMPTE experiment, in: Proceedings of the International Radiation Symposium: Current Problems in Atmospheric Radiation, edited by: Fischer, H., A. Deepak Publishing, Busan, Korea, 2006.

Eck, T. F., Holben, B. N., Reid, J. S., Dubovik, O., Smirnov, A., O'Neill, N. T., Slutsker, I., and Kinne, S.: Wavelength dependence of the optical depth of biomass burning, urban, and desert dust aerosols, J. Geophys. Res., 104, 31333-31349, 1999.

Eck, T. F., Holben, B. N., Ward, D. E., Dubovik, O., Reid, J. S., Smirnov, A., Mukelabai, M. M., Hsu, N. C., O’Neill, N. T., and Slutsker, I.: Characterization of the optical properties of biomass burning aerosols in Zambia during the 1997 ZIBBEE Field Campaign, J. Geophys. Res., 106, 3425-3448, 2001.

García, O. E., Díaz, A. M., Expósito, F. J., Díaz, J. P., Dubovik, O., Dubuisson, P., Roger, J.-C., Eck, T. F., Sinyuk, A., Derimian, Y., Dutton, E. G., Schafer, J. S., Holben, B., and García, C. A.: Validation of AERONET estimates of atmospheric solar fluxes and aerosol radiative forcing by groundbased broadband measurements, J. Geophys. Res., 113, D21207, doi:10.1029/2008JD010211, 2008.

García, O., Díaz, A., Expósito, F., Díaz, J., Redondas, A., and Sasaki, T.: Aerosol radiative forcing and forcing efficiency in the UVB for regions affected by Saharan and Asian mineral dust, J. Atmos. Sci., 66, 1033-1040, doi:10.1175/2008JAS2816.1, 2009.

García, O. E., Expósito, F. J., Díaz, J. P., and Díaz, A. M.: Radiative forcing under aerosol mixed conditions, J. Geophys. Res., 116, D01201, doi:10.1029/2009JD013625, 2011a.

García, O. E., Expósito, F. J., Díaz, J. P., Díaz, A. M., Dubovik, O., and Derimian, Y.: Climate Models, chap. Aerosol Radiative Forcing: AERONET-based estimates, InTech Open Access Publisher, ISBN 979-953-307-338-4, $2011 \mathrm{~b}$.

Hansen, J., Sato, M., Kharecha, P., and von Schuckmann, K.: Earth's energy imbalance and implications, Atmos. Chem. Phys., 11, 13421-13449, doi:10.5194/acp-11-13421-2011, 2011.

Haywood, J., Francis, P., Osborne, S., Glew, M., Loeb, N., Highwood, E., Tanré, D., Myhre, G., Formenti, P., and Hirst, E.: Radiative properties and direct radiative effect of Saharan dust measured by the C-130 aircraft during SHADE: 1 . Solar spectrum, J. Geophys. Res., 108, 8577, doi:10.1029/2002JD002687, 2003.

Holben, B. N., Eck, T. F., Slutsker, I., Tanré, D., Buis, J. P., Setzer, A., Vermote, E., Reagan, J. A., Kaufman, Y., Nakajima, T., Lavenu, F., Jankowiak, I., and Smirnov, A.: AERONET - A federated instrument network and data archive for aerosol characterization, Remote Sens. Environ., 66, 1-16, 1998.

Holben, B., Tanré, D., Smirnov, A., Eck, T., Slutsker, I., Abuhassan, N., Newcomb, W. W., Schafer, J., Chatenet, B., Lavenue, F., Kaufman, Y., Castle, J. V., Setzer, A., Markham, B., Clark, D., Frouin, R., Halthore, R., Karnieli, A., O'Neill, N., Pietras, C., Pinker, R., Voss, K., and Zibordi, G.: An emerging ground-based aerosol climatology: Aerosol Optical Depth from AERONET, J. Geophys. Res., 106, 12067-12097, 2001.

IPCC: The Physical Science Basis, Fourth Assessment Report Summary, Intergovernmental Panel on Climate Change, Cambridge University Press, New York, 2007.

Kaufman, Y., Koren, I., Remer, L., Tanré, D., Ginoux, P., and Fan, S.: Dust transport and deposition observed from the Terra-
Moderate Resolution Imaging Spectroradiometer (MODIS) spacecraft over the Atlantic Ocean, J. Geophys. Res., 110, D10S12, doi:10.1029/2003JD004436, 2005.

Koren, I., Kaufman, Y., Remer, L., and Martins, J.: Measurement of the Effect of Amazon Smoke on Inhibition of Cloud Formation, Science, 303, 1342-1345, 2004.

Li, X. and Strahler, A. H.: Geometrical-optical bidirectional reflectance modeling of the discrete crown vegetation canopy: Effect of crown shape and mutual shadowing, IEEE Trans. Geosci. Remote Sens., 30, 276-292, 1992.

Lacis, A. A. and Oinas, V.: A description of the correlated $k$ distribution method for modeling nongray gaseous absorption, thermal emission, and multiple scattering in vertically inhomogeneous atmosphere, J. Geophys. Res., 96, 9027-9063, 1991.

Lohmann, U. and Feichter, J.: Global indirect aerosol effects: a review, Atmos. Chem. Phys., 5, 715-737, doi:10.5194/acp-5-7152005, 2005.

McArthur, L., Halliwell, D., Niebergall, O., O’Neill, N., Slusser, J., and Wehrli, C.: Field comparison of network Sun photometers, J. Geophys. Res., 108, 4596, doi:10.1029/2002JD002964, 2003.

Mishchenko, M. I., Travis, L. D., Kahn, R. A., and West, R. A.: Modeling phase functions for dustlike tropospheric aerosols using a shape mixture of randomly oriented polydisperse spheroids, J. Geophys. Res., 102, 16831-16847, 1997.

Moody, E. G., King, M. D., Platnick, S., Schaaf, C. B., Gao, F.: Spatially complete global spectral surface albedos: Value-added datasets derived from Terra MODIS land products, IEEE Trans. Geosci. Remote Sens., 43, 144-158, 2005.

Moody, E. G., King, M. D., Schaaf, C. B., and Platnick, S.: MODISderived spatially complete surface albedo products: Spatial and temporal pixel distribution and zonal averages, J. Appl. Meteorol. Clim., 47, 2879-2894, 2008.

Myhre, G., Berntsen, T. K., Haywood, J. M., Sundet, J. K., Holben, B. N., Johnsrud, M., and Stordal, F.: Modeling the solar radiative impact of aerosols from biomass burning during the Southern African Reginal Science Iniative (SAFARI-2000) experiment, J. Geophys. Res., 108, 8501, doi:10.129/2002JD002313, 2003.

Prospero, J. M., Ginoux, P., Torres, O., Nicholson, S. E., and Grill, T. E.: Environmental characterization of global sources of atmospheric soil dust identified with the Nimbus 7 Total Ozone Mapping Spectrometer (TOMS) absorbing aerosol product, Rev. Geophys., 40, 1002, doi:10.1029/2000RG000095, 2002.

Rodríguez, S., Alastuey, A., Alonso-Pérez, S., Querol, X., Cuevas, E., Abreu-Afonso, J., Viana, M., Pérez, N., Pandolfi, M., and de la Rosa, J.: Transport of desert dust mixed with North African industrial pollutants in the subtropical Saharan Air Layer, Atmos. Chem. Phys., 11, 6663-6685, doi:10.5194/acp-11-66632011, 2011.

Ross, J. K.: The radiation Regime and Architecture of Plant Stands, The Hague-Boston-London: Dr. W. Junk Publishers, 1981.

Roger, J.-C., Mallet, M., Dubuisson, P., Cachier, H., Vermote, E., Dubovik, O., and Despiau, S.: A synergetic approach for estimating the local direct aerosol forcing: Applications to an urban zone during the ESCOMPTE experiment, J. Geophys. Res., 111, D13208, doi:10.1029/2005JD006361, 2006.

Russak, V., Kallisa, A., Jeveerb, A., Ohviril, H., and Teralc, H.: Changes in the spectral aerosol optical thickness in Estonia (1951-2004), Proc. Estonian Acad. Sci. Biol. Ecol., 56, 69-76, 2007. 
Satheesh, S. and Moorthy, K.: Radiative effects of natural aerosols: A review, Atmos. Environ., 39, 2089-2110, 2005.

Schafer, J., Eck, T., Holben, B., Artaxo, P., Yamasoe, M., and Procopio, A.: Observed Reductions of Total Solar Irradiance by Biomass-Burning Aerosols in the Brazilian Amazon and Zambian Savanna, Geophys. Res. Lett., 29, 1823-1826, 2002.

Smirnov, A., Holben, B., Eck, T., Dubovik, O., and Slutsker, I.: Cloud screening and quality control algorithms for the AERONET data base, Remote Sens. Environ., 73, 337-349, 2000.

Smirnov, A., Holben, B., Kaufman, Y., Dubovik, O., Eck, T., Slutsker, I., Pietras, C., and Halthore, R.: Optical properties of atmospheric aerosol in maritime environments, J. Atmos. Sci., 59, 501-523, 2002.

Smirnov, A., Holben, B. N., Lyapustin, A., Slutsker, I., and Eck, T. F.: AERONET processing algorithms refinement, in: AERONET Workshop, El Arenosillo, Spain, 2004.
Sinyuk, A., Dubovik, O., Holben, B. N, Eck, T. F., Breon, F. -M., Martonchik, J., Kahn, R., Diner, D. J., Vermote, E. F., Roger, J. -C., Lapyonok, T., and Slutsker, I.: Simultaneous retrieval of aerosol and surface properties from a combination of AERONET and satellite data, Rem. Sens. Environ., 107, 90-108, 2007.

Twomey, S.: Atmospheric aerosols, Elsevier Scientific Pub. Co., New York, USA, USA, 1977.

Wanner, W., Li, X., and Strahler, A. H.: On the derivation of kernels for kernel-driven models of bidirectional reflectance, J. Geophys. Res., 100, 21077-21089, 1995.

Ward, D. E., Susott, R. A., Kaufman, J. B., Babbitt, R. E., Cummings, D. L., Dias, B., Holben, B. N., Kaufman, Y. J., Rasmussen, R. A., and Setzer, A. W.: Smoke and fire characteristics for cerrado and deforestation burns in Brazil: Base-B experiment, J. Geophys. Res., 97, 14601-14619, 1992.

Ward, D. E., Hao, W. M., Susott, R. A., Babbitt, R. E., Shea, R. W., Kaufman, J. B., and Justice, C. O.: Effect of fuel composition on combustion efficiency and emission factors for African savanna ecosystems, J. Geophys. Res., 101, 23569-23576, 1996. 